\title{
A History of Organic Geochemistry
}

\author{
B. Durand ${ }^{1}$ \\ 1 Bernard Durand, 2, rue des Blés-d'Or, Dizée, 17530 Arvert - france \\ e-mail: bledor@wanadoo.fr
}

Résumé - Histoire de la géochimie organique — La géochimie organique est née des interrogations sur l'origine du pétrole. Son développement a pour l'instant été lié à celui de l'exploration pétrolière. Elle ne s'est constituée en science autonome qu'un peu après 1960. Les années 1965-1985 furent particulièrement productives : pendant cette période les mécanismes de la formation des gisements de pétrole et de gaz naturel furent explicités et de nombreux biomarqueurs, témoins de l'origine organique du pétrole furent identifiés. La connaissance des kérogènes, matière première de la formation du pétrole, fit également des progrès décisifs et des outils d'aide à l'exploration pétrolière virent le jour, comme les méthodes de corrélation huiles-roches mères, le Rock-Eval, et les modèles mathématiques de simulation de la formation et de la migration du pétrole. En même temps eut lieu un rapprochement avec la science des charbons et une extension de la géochimie organique à des domaines variés, tels que la sédimentologie organique, la microbiologie des sédiments ou la formation des gîtes minéraux.

La période actuelle se caractérise par une application croissante des connaissances acquises à des domaines autres que l'exploration pétrolière et par son intégration à l'ensemble des disciplines géologiques. Cette intégration a lieu, entre autres, par sa contribution au développement des «simulateurs de bassin », qui simulent mathématiquement l'évolution des bassins sédimentaires au cours du temps et la formation des gisements de pétrole et de gaz naturel qui en résulte.

Dans les années qui viennent, la géochimie organique aura encore un rôle important à jouer dans l'exploration et la production du pétrole et plus généralement des combustibles fossiles. Mais son avenir à plus long terme est probablement dans l'étude des interactions des produits de l'activité humaine, en particulier les polluants organiques et les gaz à effet de serre, avec la géosphère, en relation avec la recherche d'un développement durable et la compréhension des mécanismes des changements climatiques.

Le développement de la géochimie organique moderne doit beaucoup aux instituts professionnels de recherche et en particulier à deux d'entre eux, l'Institut français du pétrole (IFP) en France et le Kernforschungsanlage (KFA) en Allemagne : il faut en créditer les créateurs et premiers animateurs des départements de géochimie organique de ces deux instituts, B. Tissot et D. Welte.

\footnotetext{
Abstract - A History of Organic Geochemistry - Organic geochemistry is the fruit of questions about the origin of petroleum, and for the time being, its development has been closely linked to that of petroleum exploration. It only became an autonomous science shortly after 1960. The years 1965-1985 were extremely productive: during this period, the mechanisms of the formation of oil and natural gas fields were clarified, and many biomarkers, testimony of the organic origin of oil, were identified. The knowledge of kerogens, the raw material for the formation of oil, also made decisive progress, and tools to aid petroleum exploration were created, such as oil-source-rock correlation methods, Rock-Eval, and mathematical models simulating the formation and migration of oil. A rapprochement took place at the same time with coal science and an extension of organic geochemistry to various fields such as organic sedimentology, the microbiology of sediments and the formation of orebodies.
} 
The current period is characterized by the growing application of the knowledge gained to fields other than petroleum exploration, and its integration with all geological disciplines. This integration has, among other factors, taken place through its contribution to the development of "basin simulators", which mathematically simulate the evolution of the sedimentary basins over time and the resulting formation of oil and natural gas fields.

In the coming years, organic geochemistry will continue to play an important role in the exploration and production of oil, and of fossil fuels in general, but its long term future probably lies in the study of interactions of the products of man's activity, in particular organic pollutants and greenhouse gases, with the geosphere, in relation with the search for sustainable development and the understanding of mechanisms of climatic changes.

The development of modern organic geochemistry owes a great deal to the professional research institutions and particularly to two of them, Institut français du pétrole (IFP) in France and Kernforschungsanlage (KFA) in Germany: credit is certainly due to the creators and the early leaders of the organic geochemistry departments of these two institutions, B. Tissot and D. Welte.

\section{A SCIENCE BORN OF PETROLEUM}

Organic geochemistry is the study of organic substances in rocks. It attempts to understand their composition, their origin, formation mechanisms, modes of deposition and distribution, as well as their relations with one another and with the mineral world. It is a young science, most of it having been acquired in less than 40 years. The beginnings of organic geochemistry are closely linked to research on the origin of petroleum.

Let us first point out that for an organic chemist, petroleum is a mixture of saturated and aromatic hydrocarbons which account for about $85 \%$ of its weight, and molecules containing "heteroelements" alongside carbon and hydrogen: mainly sulfur, oxygen and nitrogen. The large majority of heteroatomic molecules are high molecular weight molecules which are called resins and asphaltenes.

The petroleum family includes bitumens, also called asphalts, which are highly viscous and sometimes solid oils mainly containing resins and asphaltenes, as well as natural gas, which contains gaseous hydrocarbons in normal temperature and pressure conditions, and a variable proportion of nonhydrocarbon gases, chiefly carbon dioxide, hydrogen sulfide and nitrogen.

Oil and natural gas are found in sedimentary basins at depths ranging from the surface to about $10 \mathrm{~km}$, in the pores of permeable rocks of variable extension called reservoir rocks. These are generally sandstones or coarse-grained or fractured limestones. Bitumens and asphalts are found in the same type of rock, but mainly at or near the surface. Bitumens and asphalts are in fact products of the alteration of petroleum by surface waters.

\subsection{Inorganic Theory versus Organic Theory: the Scientists of the Late $19^{\text {th }}$ Century}

The understanding the origin of petroleum was for a long time merely an object of curiosity, because no economic importance was attached to it. Petroleum found at the earth's surface, chiefly in the form of bitumen outcrops (the famous Judea bitumen for example) and small surface flows supplied the only uses.

There was hardly any theory on this subject that could be qualified as scientific before the $19^{\text {th }}$ century. Emblematic scholars of the late $19^{\text {th }}$ century delved into the question: for Berthelot (1866) petroleum was the product of the action of water on inorganic carbides such as iron carbide and aluminum carbide, presumed to be present in abundance in the earth's crust. For Mendeleev (1878), who spent some time in his early career analyzing the petroleums of Pennsylvania and the Caucasus, petroleum is formed at depths where there is no longer any question of organisms. This so-called inorganic theory predominated for a very long time. L. Pasteur is said to have supported a biogenic theory, according to which petroleum was the result of bacterial action on organic debris.

The present so-called organic theory, according to which petroleum originates in the organic matter present in sedimentary rocks, took a long time to be established. Yet it already had partisans in the early $19^{\text {th }}$ century and even before: the Swiss geologist A. Jaccard, a defender of this theory, published a work in 1895 where he dates it in 1801, to L. de Buch, a scholar attached to the King of Prussia, yet the premisses of the theory can already be found in a memorandum presented in 1770 in France to the Royal Academy of Sciences by M. Fougeroux de Bondaroy. A. Jaccard and L. Buch were partisans of an origin in animal debris, while M. Fougeroux de Bondaroy proposed a plant origin. The bibliography compiled by Jaccard identifies also the work of the French geologist M. Lesquereux, who explained in a letter sent in 1865 to J. von Liebig the reasons for believing in an origin in marine plants, such as fucus.

\subsection{The Progress of Organic Theory: Hunt, White, Engler, Verdnasky, Treibs}

It is with the North American petroleum and coal geologists of the late $19^{\text {th }}$ and early $20^{\text {th }}$ century that the first truly 
comprehensive approach can be found to the mechanisms of petroleum formation, at a time when petroleum demand was growing significantly. In 1863, the Canadian petroleum geologist T.S. Hunt is also one of the fathers of the concept by which petroleum accumulates preferably in the anticlinal zones of the earth's crust; this concept was for decades and still remains one of the principal guides to petroleum exploration declared that petroleum was formed from plant and animal debris, particularly microscopic marine forms, which are present in sedimentary rocks. According to him, the transformation by which the organic matter present in the sediments becomes bitumen and petroleum is similar to that which produces so-called "bituminous" coals from peat and lignite. In 1915, the American coal geologist D. White showed that a relation existed in Pennsylvania between the location of the petroleum reservoirs and the map of "coalification" stages of the very abundant coals in the region.

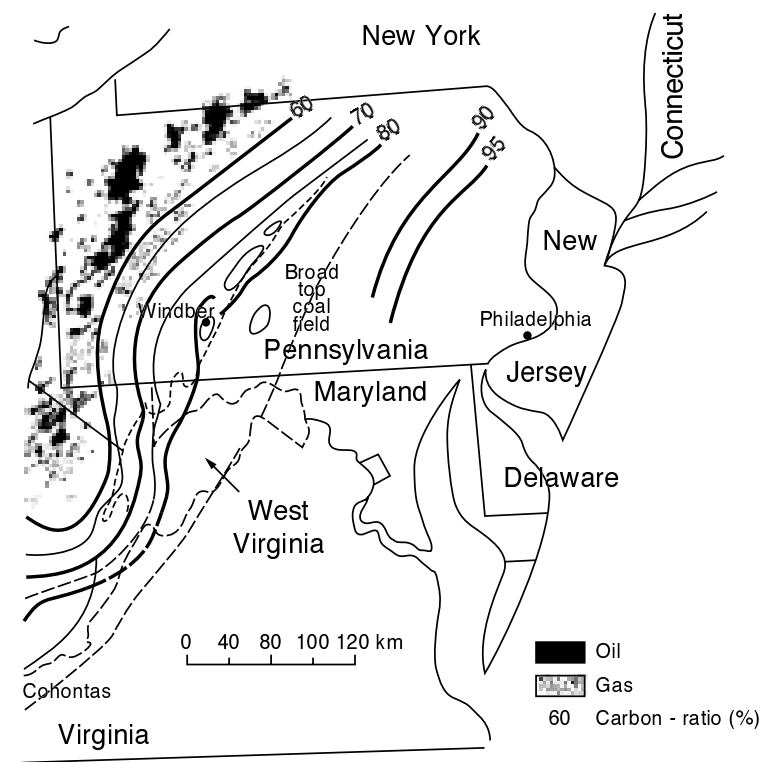

Figure 1

Location of oil and gas fields in Pennsylvania compared with isocontent curves of carbon in coals (carbon ratio), according to D. White, 1915. After Robert (1985).

Coalification is the natural mechanism of transformation that makes peat, the original organic matter of coal, as it goes through its very progressive burial in the depths of the sedimentary basins, pass through successive stages of lignite, bituminous coal, anthracite and metaanthracite. It is accompanied by physical and chemical transformations in the coals and at the time, these different stages of transformation were identified by the organic carbon content of the coal (carbon ratio), which increased with coalification. White observed that petroleum fields were only found in areas where this content was lower than a value of about $60 \%$; in the same way, natural gas fields disappeared when the carbon ratio rose above $70 \%$ (Fig. 1). White thereby concluded, as already done by T.S. Hunt, that the formation of petroleum and natural gas reservoirs and coalification were two aspects of the same mechanism of progressive transformation of organic matter in the sediments during their burial. He also stated that the intensity of this transformation could be calibrated with a simple parameter, the carbon content of the coals found in the sedimentary series.

In the late $19^{\text {th }}$ century, an industry developed in the United States and Europe producing a mineral oil similar to petroleum, by pyrolysis of rocks rich in organic matter called "oil shales" at temperatures of 400 to $500^{\circ} \mathrm{C}$. The oil produced was called "shale oil". It was therefore tempting to suggest by analogy that in nature, the factor responsible for the formation of petroleum from the sedimentary organic matter was a thermal cracking of this organic matter under the effect of increasing temperature with depth. This increase in temperature was well known to all who had drilled boreholes or conducted mining operations. The German chemist C. Engler (1888, 1912), a partisan of animal origin, tried to prove this experimentally and showed that substances similar to petroleum could be produced by pyrolyzing a variety of animal substances in the laboratory (fish, molluscs, whale oil). Investigations were also conducted at the same time with sedimentary rocks by the American geologists A.W. McCoy and P. Trager in 1919 and, according to Bordenave (1993) by the English geologists MM. Kennaby and May of the Anglo-Iranian Oil Company in 1931. Later on, the American geologist and chemist, W.E. Pratt (1943), observing variations in the chemical composition of petroleums according to their geological age, concluded that they were the result of a "progressive cracking in nature's laboratory".

Yet the temperatures necessary to produce shale oil in the oil shale industry were several hundred degrees, while such temperatures are only encountered in the surface areas of the earth's crust in volcanic regions. Besides, comparisons made between petroleums and Engler's pyrolysates show that even with the makeshift analytical resources of the time, significant differences were observed. The experiments of Engler and his imitators were therefore deemed undemonstrative to most scientists at the time.

The idea that petroleum originated in sediments containing organic matter was nonetheless well established among North American petroleum geologists in the 1930s. The concept of "source rock" was born, illustrated inter alia by the work of D. Trask (Trask and Wu, 1930; Trask et al., 1932) for whom the origin of petroleum in source rocks was 
positively established, and who wondered whether the petroleum was formed in the sediments at the time of their deposition. In 1926, the American Petroleum Institute (API) and the US Geological Survey (USGS) launched a vast program to analyze borehole cuttings and cores in order to find criteria for characterizing source rocks, a program that culminated with the publication by Trask and Patnode (1942) of the analysis of 35000 samples. These petroleum geologists, however, still failed to agree on the mechanisms of petroleum formation.

Very similar observations and investigations also took place in the early $20^{\text {th }}$ century in the Soviet Union. In 1924, the Russian geologist V.I. Verdnasky synthesized them in a work where he defended the theory of the origin of petroleum in the thermal transformation of organic matter present in sedimentary rocks. Yet he went far beyond simple observation, and firmly put petroleum formation into the

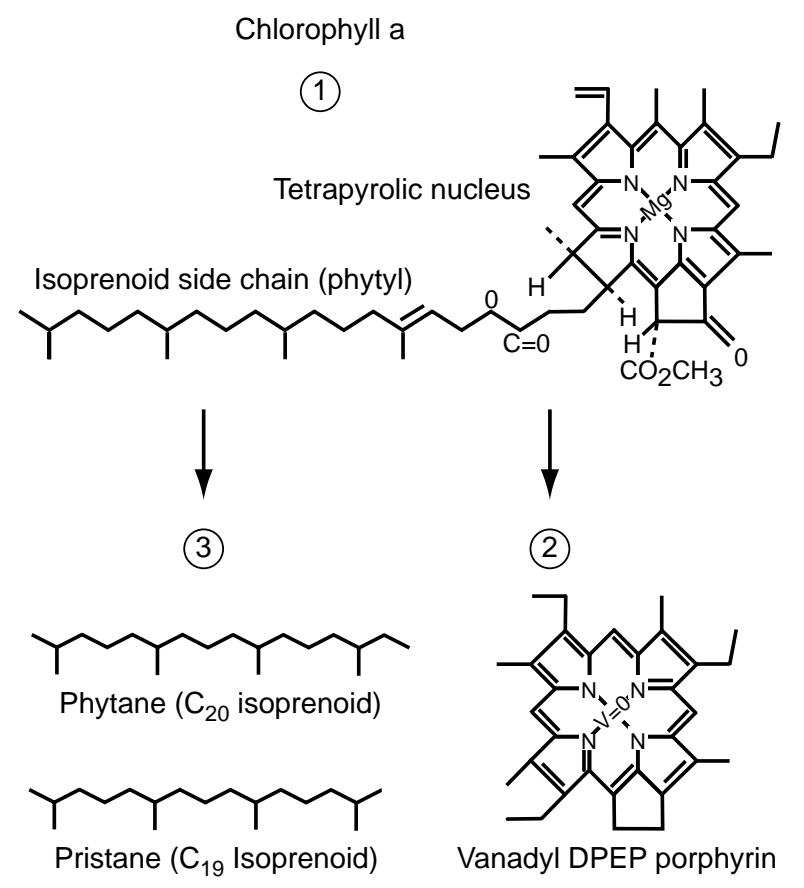

Figure 2

Chemical structure of chlorophyll a and its derivatives in sediments: the chlorophyll found in plants (1) and vanadyl DPEP porphyrin (2) found in oils possess the same tetrapyrolic nucleus. This observation led Treibs (1934) to infer that petroleum was of biological origin.

The alteration of chlorophyll in sediments by rupture of the phytyl side chain and saturation of its fragments, also leads to the formation of isoprenoid hydrocarbons (3). After Bordenave et al. (1993).

With permission of Éditions Technip. more general framework of a description of the geochemical cycle of elements and the interactions between the biosphere and geosphere. His work, translated in 1934 into English with the title "Outlines of Geochemistry", contained what could be called the first treatise of organic geochemistry. Verdnasky is therefore considered in Eastern Europe as the founder of organic geochemistry.

In 1934, the German chemist A. Treibs revealed the close similarity of chemical structure between porphyrins, organic molecules found in petroleums and in sediments, and chlorophyll pigments (Fig. 2). This relationship is considered to be the first and really undeniable proof of the organic origin of petroleum. And it is to A. Treibs that the paternity of organic geochemistry is attributed in Western Europe.

\subsection{The Theory of Direct Accumulation}

Later, the observation of the existence of traces of hydrocarbons in recent sediments, in particularly by V. Smith (1954), gave rise to the theory of direct accumulation (Baker, 1959; Meinschein, 1959). According to this theory, the mechanisms of the formation of petroleum accumulations is expulsion followed by concentration of these hydrocarbons by compaction and deformation of the sediments during their burial. This theory does not contradict the organic theory: it is rather a theory on the mechanisms of its migration, in other words, its displacement from the source rock, recent sediments in this case, up to its reservoir.

This theory was soon contradicted by the finding of wide differences in chemical structure between substances extracted from recent sediments and those found in petroleums (Stevens et al., 1956; Erdman et al., 1958). Besides, volumetric calculations demonstrated that the quantities of hydrocarbons found in the recent sediments were too small to produce large fields, and centrifuge experiments designed to simulate compaction only succeeded in extracting an infinitesimal quantity of these hydrocarbons, showing that they could not be expelled from the sediments by compaction at the same time as water (Peake and Hodgson, 1965).

\subsection{Biogenic and Radiogenic Theories}

While the organic origin of hydrocarbons found in recent sediments had not been challenged, the mechanisms of their formation had not been clarified. The American microbiologist E.C. ZoBell and his colleagues (ZoBell, 1947; Stone and ZoBell, 1952), who investigated the action of microorganisms on petroleum hydrocarbons at the time, suggested that these hydrocarbons were produced by bacteria and that the mechanism of petroleum formation was to be found there, as Pasteur himself had believed. Yet this research direction ultimately failed, because while certain bacteria were known for a long time to produce methane, all the laboratory efforts to cause bacteria to produce other 
hydrocarbons from sedimentary organic matter failed. However, the idea was not completely sterile, since, as we shall see further on "bacterial" methane proved to be the source of large fields of natural gas. It was also observed that some bacteria were capable of degrading petroleum in its reservoirs.

Also at the time appeared the theory of the formation of petroleum by the action of the radioelements. According to this "radiogenic" theory, the radiation produced by the radioelements present in sedimentary rocks caused an alteration of the organic matter and the formation of hydrocarbons (Lind, 1938). Yet this theory soon proved to be difficult to credit for quantitative and qualitative reasons. While an alteration of organic matter present in certain sediments in contact with grains of radioactive minerals is effectively sometimes observed under the microscope, as in the case of Alum shales for example, shales of Silurian age rich in radioactive minerals found in Scandinavia, the mechanism was too rare for generalization, and the analyses of the products formed showed that their composition was very far from that of common petroleums (Whitehead, 1951). Yet radioactive decay is probably the cause of a large part of the helium and argon found in certain natural gas reservoirs.

\subsection{Growing Petroleum Demand and the Creation of EAOG}

1960 was the year of entry into the petroleum era, when petroleum became the main source of energy for humanity. Petroleum demand started growing rapidly, while most of the shallow reservoirs had been discovered, usually next to surface leaks (the oil "shows"). No method of direct detection in depth had been imagined. The exploration managers in the oil companies then realized that they increased their chances of finding oil if they clearly understood the mechanisms of formation and accumulation in the reservoirs. Specialized laboratories therefore increasingly appeared in these companies and large professional institutes, led by teams of geologists and chemists who cooperated with the university laboratories interested in these matters. Publications on the origin of petroleum began to proliferate. On this subject, the bibliographic studies of Stevens (1956) and Debyser and Deroo (1969) are enlightening.

It is in Europe that the developments were the most significant:

The leading European laboratories formed the structure of the European Association of Organic Geochemistry (EAOG), which organized its first congress at Milan in 1962, and then organized the International Meeting on Organic Geochemistry every two years, the main rendezvous of organic geochemists. The proceedings of this congress are the series of Advances in Organic Geochemistry. The EAOG also struck the Treibs medal to reward the most significant efforts in organic geochemistry.
The first Gordon Research Conference in Organic Geochemistry was held in 1963 in the United States, at the Tilton School in New Hampshire, bringing together American and European organic geochemists. This conference, alongside the EAOG conference, marks the activity of this discipline today.

1963 also saw the publication by I. Breger et al. of the first book with the title Organic Geochemistry. Organic geochemistry had therefore acquired all the attributes of an autonomous science. Yet the participants at the first Gordon Research Conference in Organic Geochemistry were divided by a finding of uncertainty not about the origin of the petroleum, because there was too much evidence of its origin in organic matter in the sediments, but about the precise mechanisms of its formation: many theories had been compared, but none was considered to offer positive proof.

\section{A PARALLEL HISTORY: COAL SCIENCE}

Coals are sedimentary rocks whose organic matter accounts for at least half of their weight. In their overwhelming majority, they were formed from debris of higher plants, particularly in the marine and lacustrine deltas of rivers crossing areas of abundant vegetation at the time of their deposition. This is why they are called humic coals (from humus, a soil formed of plant debris), as opposed to more occasional coals, coals of algae mainly formed of debris of unicellular algae and coals of spores formed chiefly of debris of plant spores. Humic coals are associated, in the sedimentary series where they are found, called "coal series", with rocks containing a lesser abundance of the same type of organic matter. The coal series may be several kilometers thick. The coal levels are rarely more than one meter thick, but can extend over several kilometers.

Coals were considered in ancient times as products of volcanic phenomena or the condensation of asphaltic materials. Their origin in the debris of higher plants was nonetheless recognized clearly from the early $19^{\text {th }}$ century. Coal geology made tremendous progress in the late $19^{\text {th }}$ century and early $20^{\text {th: }}$ : the depositional modes and eras of coal formation were investigated: the quantitative importance of coals formed in the Carboniferous, 300 to $350 \mathrm{Ma}$ ago was recognized in particular. Noteworthy among the great coal geologists of the time were C.E. Bertrand and B. Renault in France, H. Potonié in Germany and D. White in the United States. In 1913, D. White, together with the American petrographer R. Thiessen, published a work that stands as a reference The origin of coal.

Since the origin of coal was clear and coal was abundant on the earth's surface, coal science which began to develop at the time did not focus on the problems of its origin and exploration, as the case of organic geochemistry with petroleum, but on problems of a technological nature: in the 
variety of coals, what criteria could be used to recognize the fittest for their intended use: home heating, steam generation, manufacture of cast iron and steel? The aim was also to improve the industrial processes of coal utilization. Two disciplines emerged, providing each other with mutual support: coal petrography and coal physical chemistry.

Shortly after 1830 the English geologist Hutton (not to be confused with J. Hutton (1726-1797), one of the creators of modern geology), using a transmission microscope to examine thin slices of coal, discovered remains of spores and plant cells. In doing so, he founded coal petrography, a discipline that then grew considerably. In 1913, H. Winter in Germany created the technique for examination by reflection microscope on a polished block, perfected in 1927 by E. Stach with the use of a lens immersed in oil (van Krevelen, 1981). In 1943, the German petrographer M. Schochardt introduced the technique of illumination with ultraviolet light, which made fluorescent some of the composants examined under the microscope.
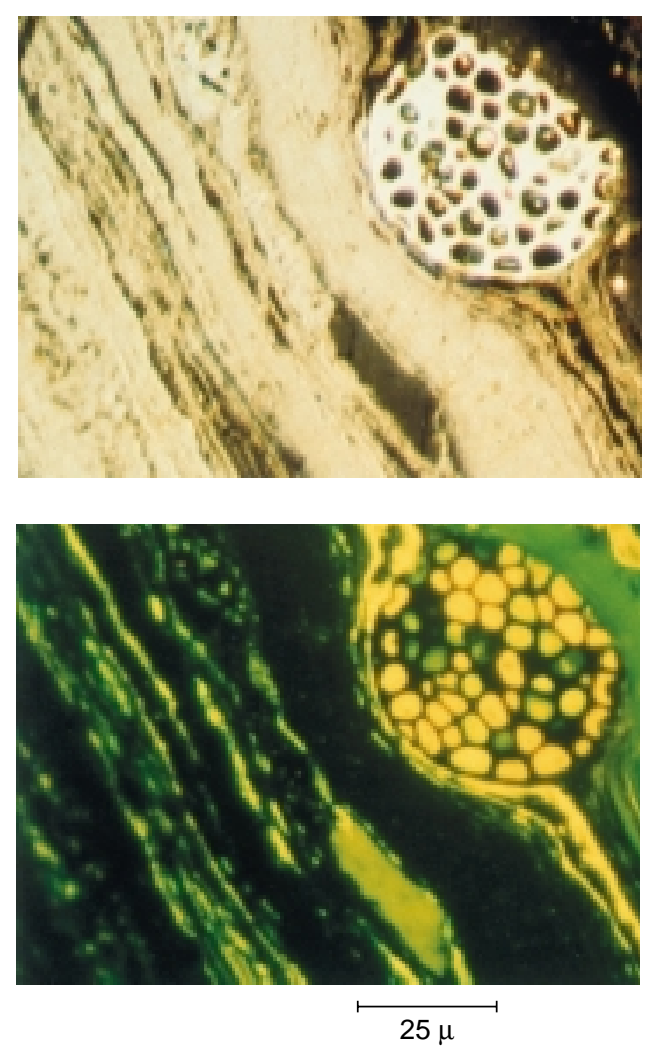

Figure 3

Microphotographs in reflected light of coal fragments bound in a resin. At top, illumination with light at $546 \mathrm{~nm}$. The medium reflectance particles are vitrinite, and the low reflectance particles, which are dark, liptinite, and the high reflectance particles inertinite (a mushroom stalk here). At bottom, ultraviolet illumination causes fluorescence of the liptinite particles. Photographs B. Alpern.
Coal petrography witnessed a conceptual advance alongside its technical progress: the objects observed under microscope were classed according to their biological origin. Particularly noteworthy was the work in France of H. Fayol and in England the work of C.A. Seyler and M. Stopes. Stopes named these objects maceral by analogy with rock minerals and, in 1919, proposed the so-called Heerlen classification which, in 1935, became the base of the one used today. This classification was improved later on by the German petrographers E. Stach, M.Th. Mackowsky and M. Teichmüller (Stach et al., 1982), the Dutch petrographer P. Jongmans and the French petrographer B. Alpern, among others.

Macerals belong to three main families (Fig. 3), classed primarily by their reflectance under the reflecting microscope. Their biological origin can be identified easily in most cases.

The vitrinite family, with medium reflectance, accounts for about $70 \%$ of the coal on average. The macerals of this family are gels formed in sedimentation environments from lignocellulose debris (wood) of higher plants.

The liptinite family, with low reflectance, contains exinites, formed from the "outer parts of plants": spores, pollens, leaf cuticles, the alginites from unicellular algae initially living in the sedimentation environment, and miscellaneous amorphous substances. The macerals of this family display the feature of becoming fluorescent under ultraviolet light.

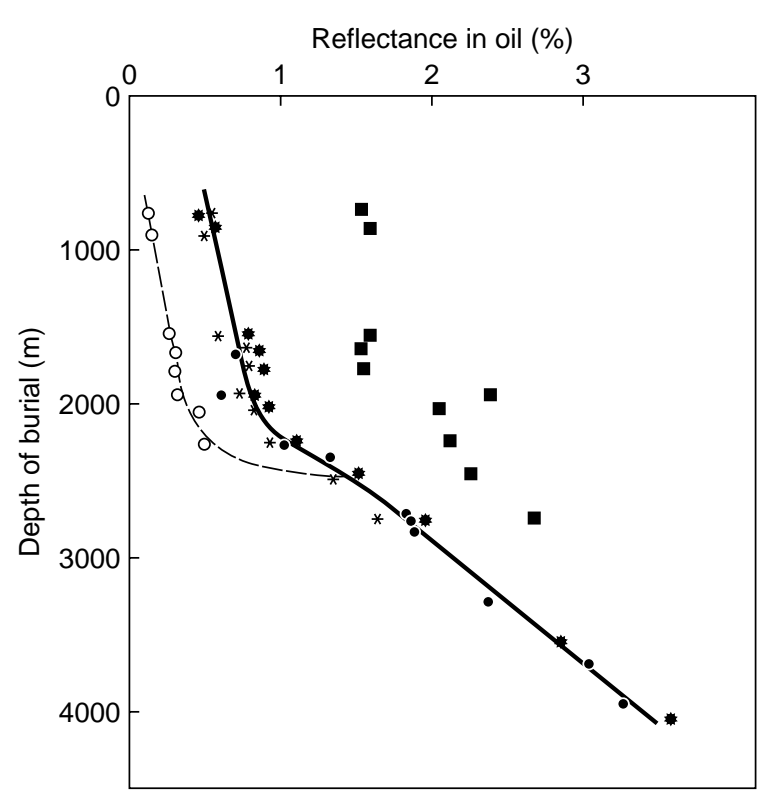

Figure 4

Example of variation reflectance of coal macerals with depth (and generally type 3 kerogens): the Logbaba (Cameroon) boreholes: vitrinite in solid lines and liptinite in dotted lines. The black squares represent inertinite. After Durand and Espitalié (1976). 
The inertinite family, with high reflectance, mainly consists of particles that were oxidized before or during sedimentation, for example under the effect of forest fires or residence or prolonged transport in aerobic media.

Petrographic examination helps to observe the wide variety of coals and connect it with the variety of depositional environments. It also helps to anticipate the technological properties and identify the stages of coalification. The vitrinite reflectance measured in standard conditions (light of wave length $546 \mathrm{~nm}$, normal incidence to a perfectly polished section, lens with immersion in oil of index 1.517), which increases steadily during coalification, from about $0.2 \%$ in the peat stage to $3 \%$ or more in the anthracite and metaanthracite stage (Fig. 4) is the most widely used for this latter use. The best summary of the petrographic research of the time is no doubt the work by Stach (1935), Lehrbuch der Kohlenpetrographie.

Coal physical chemistry developed at the same time as petrography. The pioneers, most of whom worked in institutes dedicated to these studies, include the following: concerning the more chemical aspects, in England W.A. Bone at the Imperial College of London and R.W. Wheeler in Sheffield, and in Germany, F. Fischer at Mülheim and F. Bergius who had the rare distinction at the time of financing his own researches-concerning the more technological aspects, E. Audibert in Montluçon in France, F.S. Sinnatt in Greenwich in England and A.C. Fieldner in Pittsburgh in the United States. Research institutions employing many researchers were then created in many countries: Belgium, Spain, Holland, Poland, Yugoslavia, USSR, China, India, and Australia. All the efforts were aimed at a better understanding of the composition and chemical structure of coals, their mechanical and rheological properties, surface properties etc., to improve the industrial processes in which they were used and to discover new uses. One of the major problems to be solved was to improve the quality of metallurgical coke, which is a reducing agent and an energy supply in the production of cast iron and steel.

The best summary of the work done at the time in physical chemistry of coals is no doubt the work by D.W. van Krevelen Coal, Typology, Physics, Chemistry, Constitution (1961, reprinted in 1981). In 1950, this researcher also proposed a rectangular diagram for use in determining the properties of coals and their macerals, plotting the $\mathrm{O} / \mathrm{C}$ atomic ratios on the $x$-axis and the H/C on the $y$-axis. This "van Krevelen's diagram" proved to be invaluable in monitoring the coalification process. It is therefore an excellent tool for synthesis between physical chemistry and petrography. It went on to be very popular with petroleum geochemists.

However, coal science and organic geochemistry were completely unrelated at the time. One exception was the work of M. Teichmüller, who published a still classic article in 1958 on the location of oil and gas reservoirs around the
Bramsche Massiv in Germany, which is a volcanic intrusion in sedimentary formations containing levels with organic matter. The temperature elevation of the sediments resulting from this intrusion caused the formation of oil and gas fields from the organic matter; the zones where they are found are bounded by vitrinite isoreflectance curves, indicating a relation between coalification stages and oil and gas formation stages. This work is very similar in principle to that of D. White on the oil fields in Pennsylvania.

\section{1965-1985: THE YEARS OF EXPANSION}

\subsection{The Successors of Hunt and Verdnasky}

It is important to consider those who demonstrated the mechanisms of the formation and accumulation of oil by primarily relying on geological observations along the path initiated by T.S. Hunt and V.I. Verdnasky. In the western world, the most significant pioneering work was no doubt done by Philippi (1965) at Shell, Louis and Tissot (1967) at the Institut français du pétrole, and Albrecht and Ourisson (1969) at the University of Strasbourg. These researchers used organic solvents (chloroform, methanol, benzene) to extract series of sedimentary rock samples rich in organic matter taken by petroleum boreholes at different depths in homogeneous sedimentary series. The extracted fraction, called the soluble extract or bitumen, also contained hydrocarbons. This extraction left an insoluble fraction in the sediments, quantitatively the largest fraction, called kerogen by Forsman and Hunt (1958). The series originated in different sedimentary basins with considerable variations in the type of sediment, age, geothermal gradient and burial rate, but they all had one common feature: at the time the sediments were deposited, i.e. in the recent sediment stage, the samples of each series had very similar mineralogical and organic compositions. In consequence, the analysis of samples taken at increasing depths revealed the effects of burial on a material that was initially the same, all other things remaining equal.

All the observations led to the same conclusion: the progressive burial of the sedimentary organic matter increased the formation of hydrocarbons, first liquid, and then gas. It was also observed that the depth at which the formation of oil began was also shallower as the average geothermic gradient of the basin was lower and/or the age of the basin was higher, suggesting that the formation of oil obeyed rules of chemical kinetics (Tissot et al., 1975). Moreover, the hydrocarbons extracted from shallow sediments were very different from those found in the oilfields, but the resemblance grew progressively with burial: a minimum depth of about 1 to $2 \mathrm{~km}$ was necessary for a mixture of hydrocarbons to be formed in the sediments, with a composition close to those found in the reservoirs. 


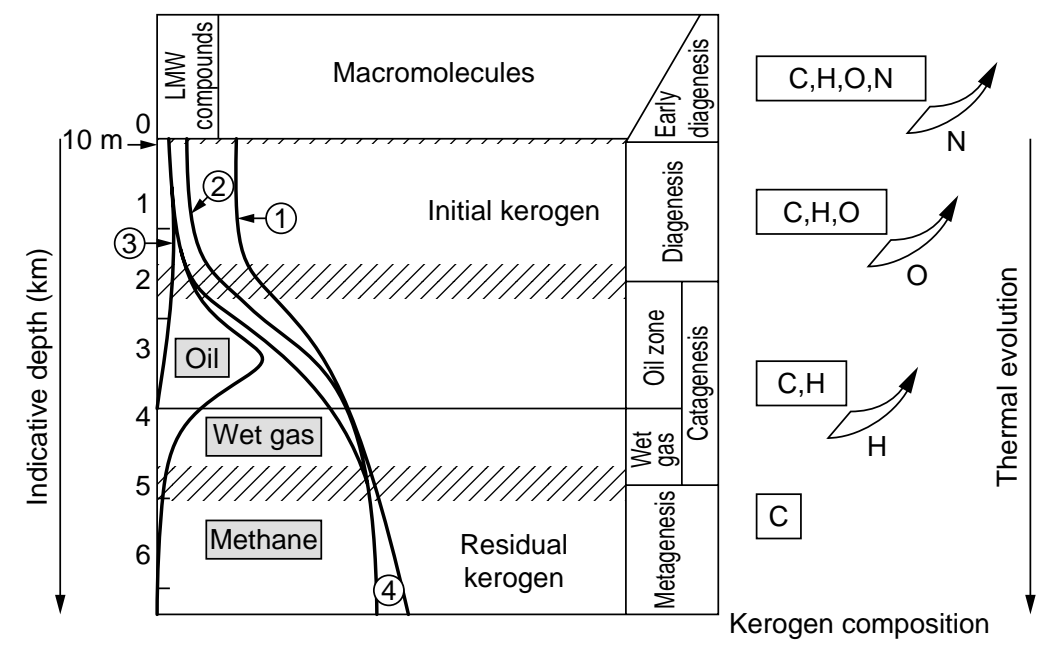

Figure 5

Flowsheet of the formation of oil and gas from kerogen as a function of depth. 1) low molecular weight oxygenated compounds; 2) resins and asphaltenes; 3) biomarkers; 4) insoluble pyrobitumen (coke) formed from oil as a consequence of gas formation. After Tissot and Welte (1978), Durand (1980) and Vandenbroucke et al. (1993) in Bordenave et al. (1993).

With permission of Éditions Technip.

Identical conclusions were drawn at approximately the same time by Russian researchers, particularly A. Kartsev, V. Sokolov and N. Vassoievich (Vassoievich et al., 1969; Kartsev et al., 1971), who had samples and documents taken from the immense variety of sedimentary basins of the Soviet Union. Since the only variable parameters in each of the series investigated was the temperature, pressure and time associated with burial, it was necessary to conclude that these variants were responsible for the formation of oil in the sedimentary basins. Since pressure could hardly cause the radical chemical transformations observed and would rather tend to delay them, temperature and time were the best candidates. These observations finally led to the establishment of a flowsheet for the formation of oil and natural gas as shown in Figure 5, which is commented on here.

In recent sediments, only a very small part of the organic matter present is extractable in organic solvents. Kerogen hence forms most of the sedimentary organic matter at this stage. The extractable fraction, bitumen, mainly contains high molecular weight and strongly functionalized molecules, belonging to categories called resins and asphaltenes, which cannot be analyzed molecule by molecule. The molecules that could be separated and analyzed were mainly geochemical fossils, i.e. molecules undeniably deriving from biological molecules. There were very few hydrocarbons among them.

During their burial, sediments containing organic matter are exposed to increasing temperatures. Three successive stages of a transformation called maturation are then observed; they were called diagenesis, catagenesis and metagenesis by Tissot and Welte (1978). Maturation corresponds to a thermal cracking of the kerogen under the effect of the rise in temperature accompanying the burial of the sediments.

During diagenesis, very few hydrocarbons are formed. This is why diagenesis is also called the immature stage by petroleum geochemists. Mobile oxygenated products, particularly water and carbon dioxide, as well as resins and asphaltenes, are liberated at this stage by the thermal degradation of the kerogen. Catagenesis, the second stage, is that of the oil, and then of the "wet" thermal gas, so called because it is a mixture of gaseous and liquid hydrocarbons. This thermal gas is formed from the remaining kerogen but also from the oil already formed, which explains why the formation of oil passes through a peak in the figure. During catagenesis, the gas/oil ratio steadily increases and the geochemical fossils, which are fragile molecules, are progressively destroyed. At the end of catagenesis, the kerogen has practically lost its capacity to produce hydrocarbons. The third stage, metagenesis, is that of the dry thermal gas, so called because the hydrocarbons it contains are gaseous hydrocarbons. This gas is formed from the remaining kerogen, but mainly from the oil and wet gas previously formed.

Finally, a general description of the formation of oil and gas and their accumulation in the reservoirs materializes. It is illustrated in Figure 6.

After their formation during burial, oil and natural gas are expelled from their source rock, in a process called primary migration, and then travel in permeable drains towards traps where they accumulate, in a process called secondary migration. These traps consist of a permeable "reservoir rock" and a permeability barrier which stops the hydrocarbons from advancing. They are usually located in the upper zones of the geological structures, the anticlines. The oil and gas can also escape from the traps to form surface shows or secondary reservoirs. This process is called tertiary migration.

The formation of the oxygenated molecules followed by oil and gas necessarily also results in a progressive modification of the physicochemical properties of the kerogen, the insoluble fraction of sedimentary organic matter (McIver, 1967; Durand and Espitalié, 1973; Tissot et al., 1974). The observation of these changes by a variety of physicochemical 

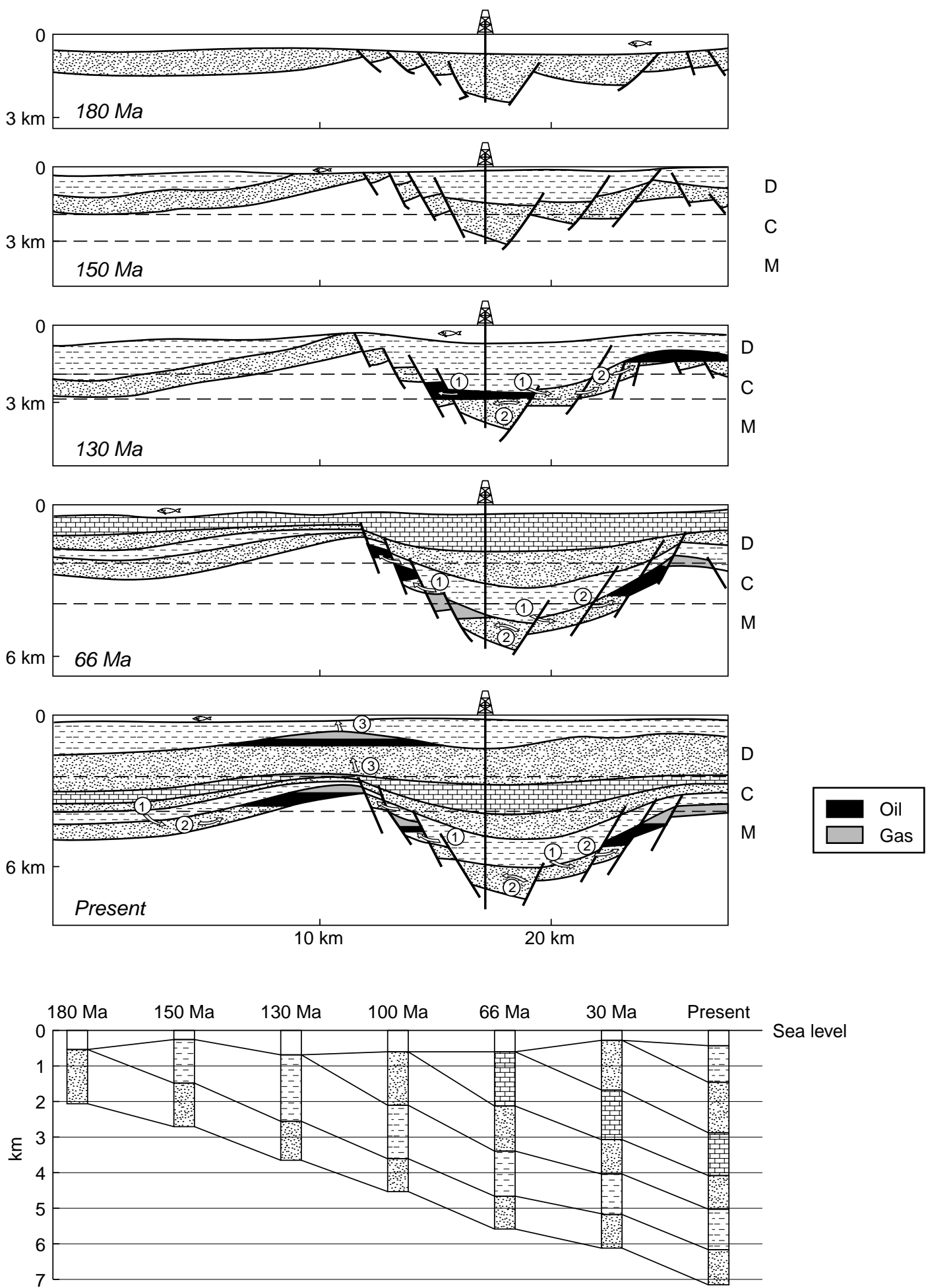

Figure 6

Flowsheet of the formation of oil and gas reservoirs in a sedimentary basin during its burial, based on the example of the Viking graben in the North Sea. Upper part of the figure represents the successive steps in the evolution of a basin of a rock rich in organic matter and buried to increasing depths and temperatures. The oil and gas formed in this source rock at stages $\mathrm{C}$ (catagenesis) and $\mathrm{M}$ (metagenesis) have been expelled (arrows 1) towards drains where they flow (arrows 2) to accumulate in traps and form fields. They could ultimately escape from these traps (arrows 3) to form secondary fields higher up. Lower part of the figure shows the evolution, over geological time, of the disposition and burial of levels identified at the fictitious well at the center of the basin. 
methods was mainly the achievement of Durand et al. (1980), who were also among the earliest to develop relations between organic geochemistry and coal science.

Kerogens are formed mainly of carbon, hydrogen and oxygen. They also contain nitrogen, but much less than the living matters in which they originate, as well as sulfur, more on average than living matter. A convenient method to track the evolution of kerogens as a function of burial of the sediments and to characterize their variety is hence a $\mathrm{C}, \mathrm{H}, \mathrm{O}$ diagram. Durand et al. selected the rectangular diagram already used by the Dutch researcher van Krevelen (1950) to track the physicochemical changes in coals, a diagram in which the $\mathrm{O} / \mathrm{C}$ atomic ratios are plotted on the $x$-axis and the $\mathrm{H} / \mathrm{C}$ atomic ratios on the $y$-axis (Fig. 7).

In this diagram, the kerogens isolated from series of sediments in which the organic matter was approximately the same at the time of deposition, are grouped together in narrow zones called evolution or maturation tracks by Durand and Espitalié (1973). Kerogens of the shallower sediments have high $\mathrm{O} / \mathrm{C}$ and $\mathrm{H} / \mathrm{C}$ atomic ratios. Diagenesis results in a greater decrease in $\mathrm{O} / \mathrm{C}$ than $\mathrm{H} / \mathrm{C}$, corresponding to the liberation of carbon dioxide and water. Catagenesis results in a sharp decrease in $\mathrm{H} / \mathrm{C}$, corresponding to the liberation of hydrocarbons. Metagenesis does not result in any substantial change, because at this stage, the kerogens have lost most of their oxygen and hydrogen, and have become carbonaceous residues, but the dark-field electron microscopy shows that this step corresponds to the development of an organization of the carbon into small

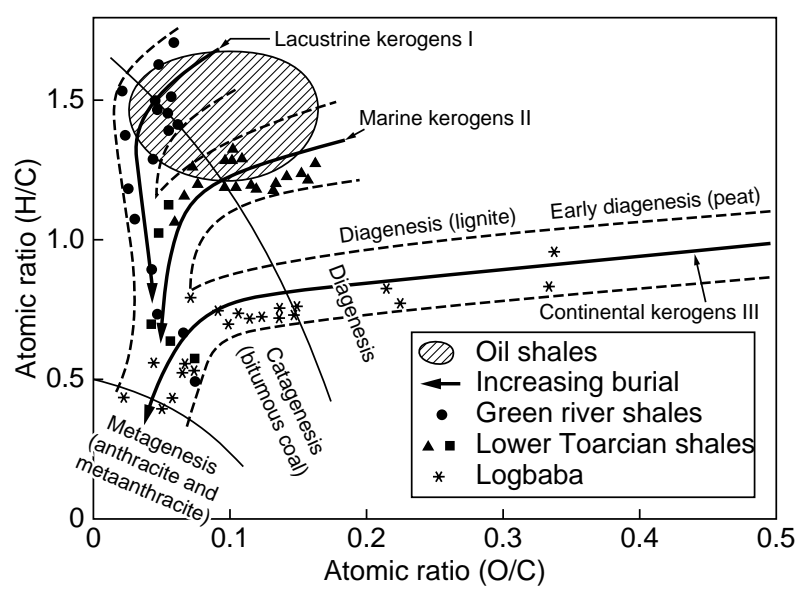

Figure 7

Evolution (maturation) pathways of kerogens of the three reference types in a van Krevelen's diagram. Also indicated are the position in this diagram of the kerogens present in oil shales and the correspondence between the main steps in the formation of oil and gas with those of coalification. After Durand and Espitalié (1973), Tissot et al. (1974) and Durand (1987). "graphitoid" domains measuring some tens to hundreds of microns, formed of stacks of roughly parallel polyaromatic sheets (Oberlin et al., 1974).

The kerogen maturation tracks of the different series analyzed are also not merged in the diagram and are distinguished according to the sedimentology of the series examined. Thus Tissot et al. (1974) distinguished between three types of reference of sedimentary organic matter:

- type 1, from a planktonic biomass thoroughly reworked by bacteria in lacustrine or evaporitic sediments;

- type 2, from a marine planktonic biomass;

- type 3, from debris of higher terrestrial plants (Fig. 10).

Their maturation paths converge towards the carbon pole of the diagram with increasing depth. Kerogens initially with the highest $\mathrm{H} / \mathrm{C}$ ratios are those that produce the most oil per unit weight during maturation. The composition of the oils formed differs according to the type and evolves as a function of maturation.

The diagram allows an easy classification of fossil fuels. These belong to three categories.

- Oils and allied substances which are asphalts or bitumens and natural gas: as we have seen, these are by-products of thermal cracking of the kerogens during their maturation. Natural gas is produced at the end of maturation, while asphalts and bitumens are the degradation product of oil in the reservoirs.

- Coals: these are in fact sediments very rich in organic matter. In the vast majority of cases, coals are "humic" coals, i.e. where the organic matter derives from higher terrestrial plants. Hence it is a special case of type 3 kerogens, and the coalification of coals is part of the more general process of the maturation of sedimentary organic matter, as claimed by $\mathrm{D}$. White: the peat stage corresponds to the recent sediment stage, the lignite stage to diagenesis, the bituminous coal stage to catagenesis, and the anthracite and metaanthracite stages to metagenesis.

- Oil shales, which, as we have seen, are rocks rich in organic matter, from which a petroleum-like oil is produced by pyrolysis at 400 to $500^{\circ} \mathrm{C}$ called shale oil: oil shales are in fact sediments that have undergone relatively shallow burial and consequently contain a still immature kerogen. This kerogen is rich in hydrogen, hence of type 1 or 2 , and therefore has a high potential for hydrocarbon production per unit weight. Temperature causes pyrolysis of the kerogen in these rocks, in other words, an artificial maturation, comparable to the natural maturation that burial would produce.

\subsection{Treibs' Successors}

An enormous task was achieved from 1965 along the path initiated by A. Treibs. This was considerably facilitated by the rapid development of the technology of analytical 
instruments: since the invention in 1906 by M. Zswett of paper chromatography, much progress had been achieved in the separation of organic mixtures into broad chemical classes, but from 1960, the development of gas chromatography and mass spectrometry, followed in 1970 by the coupling of these two instruments, combined with major advances in chemical synthesis methods, helped make tremendous headway in the separation and identification of molecules. Rigorous analytical and comparison protocols of the components of oils and extracts of sediments by organophilic solvents were developed. This led to the identification in sediments and oils of thousands of molecules undeniably derived from biological molecules. These molecules were called geochemical fossils or biomarkers. Many of them were optically active explaining the observation made several years earlier that many oils had a rotary power over light. Among the researchers focusing on "molecular geochemistry", the most active were G. Ourisson, P. Albrecht et al. (Albrecht and Ourisson, 1971) at the University of Strasbourg, G. Eglinton, J. Maxwell et al. at the University of Bristol, P. Schenck, De Leeuw et al. (De Leeuw, 1986) at the University of Delft, J. Connan of Société nationale des pétroles d'Aquitaine in Pau, W. Seifert and M. Moldowan of Chevron in the United States, M. Radke (Radke, 1987) and J. Rulkötter at Kernforschungsanlage (KFA) in Germany. A. Petrov (Petrov, 1984) at the Institute of Geology and Exploitation of Fossil Fuels in Moscow, and E. Whitehead and A. Mackenzie of British Petroleum in England.

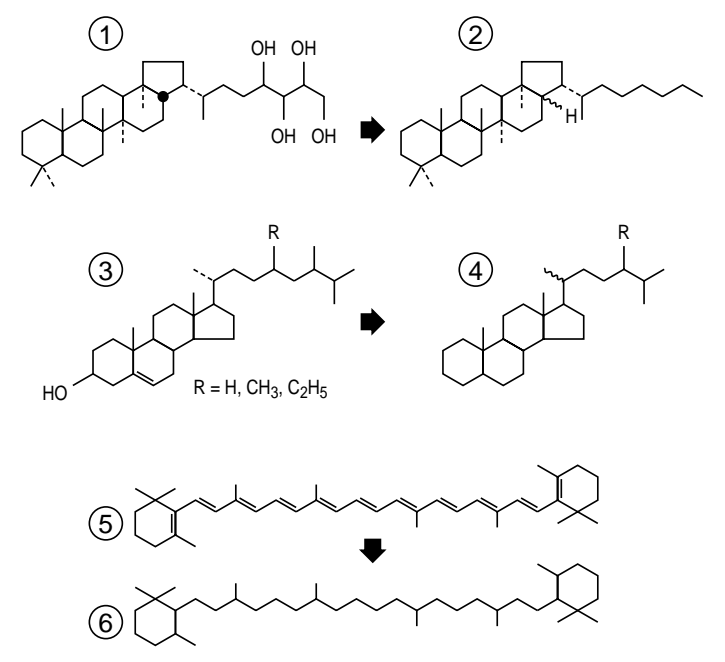

Figure 8

Structures of frequent biomarkers in sediments and oils, and biological molecules from which they derive: the bacteriohopane tetrol (1) produces hopanes (2) sterols (3) produce steranes (4) and $\beta$-carotene (5) produce $\beta$-carotane (6). In Bordenave et al. (1993).

With permission of Éditions Technip.
These molecules are for example porphyrins discovered by Treibs, as well as long chain $\mathrm{n}$-alkanes derived from the cuticular waxes of higher plants or fatty acids of marine or lacustrine plankton, isoprenoids derived from the side chain of chlorophyll pigments, as well as bacterial lipids, steroids and triterpenoids derived from the cell membranes of microorganisms, and carotenoids derived from algae and bacteria (Fig. 8). The triterpenoids of the hopane family (so named after the English botanist hope), characterized by a pentacyclic carbon skeleton, are found everywhere. According to Ourisson et al. (1979), the precursors of these molecules are present in the cell membranes of prokaryotic organisms (bacteria, blue algae) where they play the rigidifying role played by steroids in eukaryotic organisms.

Following the work of Craig, who in 1953 in the United States developed a method to measure the isotopic composition of carbon in rocks, the development occurred of the isotopic analysis of oils and organic matter in sediments, championed among others by W. Sackett (Sackett, 1975) and S.R. Silverman (Silverman and Epstein, 1958) in the United States, E.M. Galimov in the Soviet Union (Galimov, 1980), W. Stahl (Stahl, 1977), M. Schoell (Schoell, 1983) et al. in BGR in Germany. These researchers demonstrated the low $\mathrm{C}_{13}$ content of carbon in sedimentary organic matter and its derivatives, compared with that of carbonates, and helped to establish the isotopic signatures of these organic matters and their different fractions, from the isotopic composition of carbon, nitrogen and sulfur they contained.

All these results undeniably confirmed the organic origin of oil. They were used for a closer understanding of the composition of the sedimentary organic matter and oils and, above all, in the path opened up by the American geochemists Bray and Evans, who in 1961 proposed a criterion called the Carbon Preference Index (CPI) based on a measurement of the unevenness of the $\mathrm{n}$-alkanes of the $\mathrm{C}_{25}$ to $\mathrm{C}_{35}$ range, to establish what petroleum geochemists call oils/source rock correlations, i.e. the identification of the sedimentary rocks from which the oils found in the basins are derived, by comparison of their "fingerprints" provided by the distributions of the main markers-see inter alia Welte et al., 1975; Deroo (1976) and Connan (1984, 1987). They were also used to establish criteria of maturation of the source rocks as well as oils. In fact, oils, just like kerogens, find their composition evolve with the burial of their reservoir under the effect of variations in thermodynamic conditions. The example in Figure 9, after Mackenzie (1984), shows an example of the evolution of the ratio of the two enantiomer forms of a sterane with burial of the sediments. The measurement of this ratio, in principle, helps calibrate the maturation of a source rock or an oil.

However, the biomarkers are destroyed at relatively shallow depths, thereby limiting their potential in such applications to relatively immature oils. 

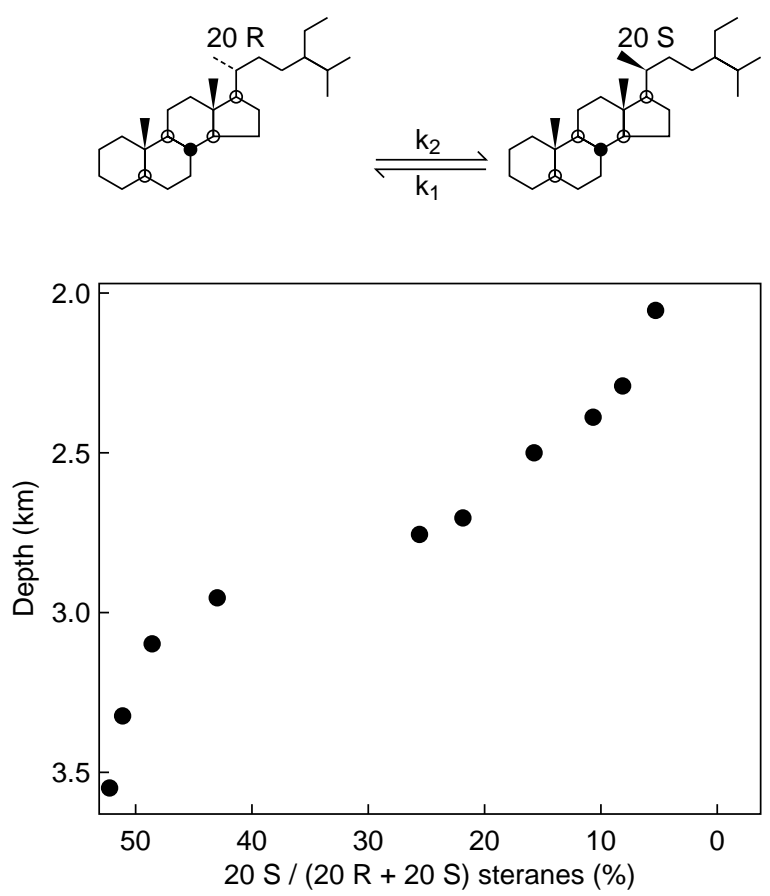

Figure 9

Example of evolution of the $20 \mathrm{~S} /(20 \mathrm{R}+20 \mathrm{~S})$ steranes ratio as a function of depth. After Mackenzie (1984).
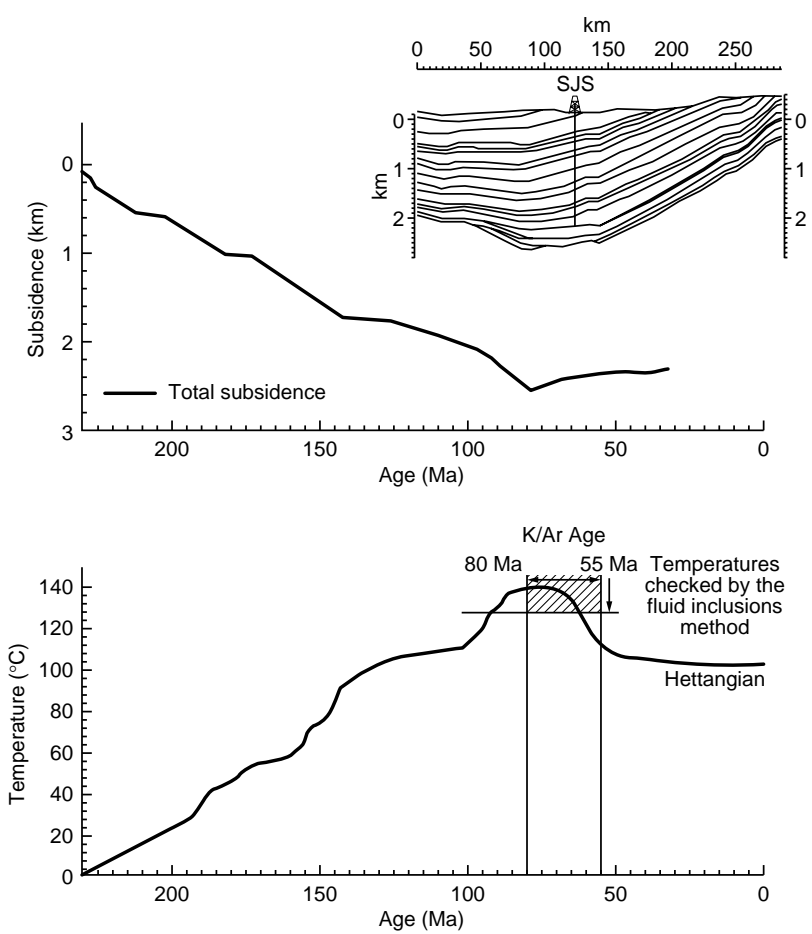

Figure 10

Evolution of burial and temperature of the Hettangian of the Paris Basin over geological time, at a well located in the central part of the basin, as indicated in the inset. After Burrus (1997).

\subsection{The Thermal Regime of the Sedimentary Basins and the Modeling of Oil Formation}

In a sedimentary basin, the temperature varies as a function of depth (on average $30^{\circ} \mathrm{C} / \mathrm{km}$, but in a range of 10 to $50^{\circ} \mathrm{C} / \mathrm{km}$ depending on the basin and the historical periods of a given basin) which itself varies as a function of time: every sedimentary layer therefore has a different thermal history (Fig. 10).

However, the temperatures reached in sedimentary basins rarely exceed $200^{\circ} \mathrm{C}$, and in some cases, oil is already found to be formed at temperatures of around $50^{\circ} \mathrm{C}$. Besides, oils also contain optically active compounds which are not stable above $200^{\circ} \mathrm{C}$, indicating that most oils are formed at lower temperatures. In fact, much higher temperatures are necessary to produce shale oil from oil shales or to form oillike products in the laboratory in Engler's experiments. This factor was much more disturbing for chemists than geochemists: it appeared impossible for some of them to produce thermal cracking reactions at temperatures as low as those. This is no doubt why they had imagined a theory on the structure of kerogens according to which they contained hydrocarbons in the occluded or adsorbed state. This only demanded relatively low temperatures, comparable to those existing in the sedimentary basins, to desorb these hydrocarbons and produce oil. Yet the question arose why extractions by solvents as powerful as methanol were incapable of extracting these hydrocarbons and why they were not liberated by heating in the laboratory at moderate temperature, as they were supposed to be during burial. Another of their ideas was that the thermal cracking reactions were catalyzed by the clay minerals, as done at the time in refineries for crude oil cracking. Yet the clay minerals are poorly crystallized and in the hydrated state in the sedimentary rocks. In these conditions, they cannot be catalysts for cracking (Durand et al., 1972).

This made it necessary to conclude that oil was formed as a result of uncatalyzed thermal cracking of kerogen at low temperature, at a very low rate, but producing very significant results at geological timescales. Moreover, the shape of the oil formation curves as a function of depth suggested that this formation obeyed rules of chemical kinetics. The chemists connected with the oil shale industry, particularly those investigating the Green River shales in the United States, the biggest accumulation now known in the world, for decades used chemical kinetics to describe the production of oil in the pyrolysis furnaces as a function of temperature and time. The work of these oil shale specialists culminated in a mathematical modeling of the production of shale oil as a function of pyrolysis temperature and time (Allred, 1966; Fausett, 1964; Braun and Rothman, 1975). One of them, P. Abelson, showed in 1963 that the kinetic parameters employed could be extrapolated to temperatures and times corresponding to the formation of oil in the sedimentary basins. 
On their side, the coal geologists and physical chemists who tried to understand the process of coalification had for long recognized the role of temperature and geological time via burial, and developed pragmatic methods and charts to describe its advancement as a function of these two parameters. A kinetics of coalification, based on a first order reaction and an Arrhenius' formalism to calculate the reaction rate had been proposed in particular by Huck and Karweil (1955) and Karweil (1955). Lopatin, a geochemist and student of Vassoevitch, imagined a simple method in 1971 to describe the formation of oil from kerogens, which was then popularized by D. Waples in 1980 under the name of the Time/Temperature Index (TTI). This method consists in assigning to each $10^{\circ} \mathrm{C}$ increment of the temperature rise during burial, a temperature factor, called the $\gamma$ factor, which is multiplied by 2 on entry into the upper $10^{\circ} \mathrm{C}$ increment. Each of these coefficients is multiplied by the residence time of the sediment, in millions of years, in the temperature interval concerned. This produces a series of increasing numbers, each corresponding to a temperature interval of $10^{\circ} \mathrm{C}$. Their sum is the TTI which is compared to a preprepared chart, in which a value of TTI corresponds to a stage of advancement of the formation of oil. For the basin investigated, the geological sections and maps can be provided with iso-TTI curves in order to delimit the most favorable zones and eras for the formation of oil.

But it was Tissot $(1969,1973)$ who had the merit of being the first to formalize the natural production of oil and natural gas by thermal cracking of kerogens, in the form of a mathematical model simulable by computer. B. Tissot illustrated the chemical structure of the kerogens in the form of immobile organic fabrics of a dimension such that they are not soluble in organic solvents, and in which the atoms are linked by chemical bonds with different rupture energies. The rupture of these bonds by an increase in temperature produces smaller structures and molecules that can then be soluble in the solvents or mobile in the sediment, such as hydrocarbons.

The thermal cracking of kerogens is accordingly described as two successive sets of independent first order reactions (parallel): the cracking of the bonds of a given type $\mathrm{i}$, whereof the quantity in a type of kerogen is characterized by its frequency xi and occurs at a rate characterized by a frequency factor $A_{i}$ and an activation energy $\mathrm{E}_{\mathrm{i}}($ Fig. 11). The temperature depends on the burial depth and hence time for the equation $\mathrm{T}=\mathrm{T}_{0}+\mathrm{g}(\mathrm{z}) \cdot \mathrm{z}(\mathrm{t})$, where $\mathrm{T}_{0}$ is the soil temperature, $\mathrm{z}(\mathrm{t})$ the depth at time $\mathrm{t}$ and $\mathrm{g}(\mathrm{z})$ the geothermal gradient at depth $\mathrm{z}$. The model can also be used to simulate pyrolysis in the laboratory.

This model contains "free" kinetic parameters $\mathrm{xi}, \mathrm{A}_{\mathrm{i}}$, and $\mathrm{E}_{\mathrm{i}}$, which must be calibrated for use in practice. This calibration was initially done by fitting to the measurements of quantities of hydrocarbons formed as a function of the depth in thoroughly investigated basins like the Paris Basin,
Kerogen-degradation mechanism
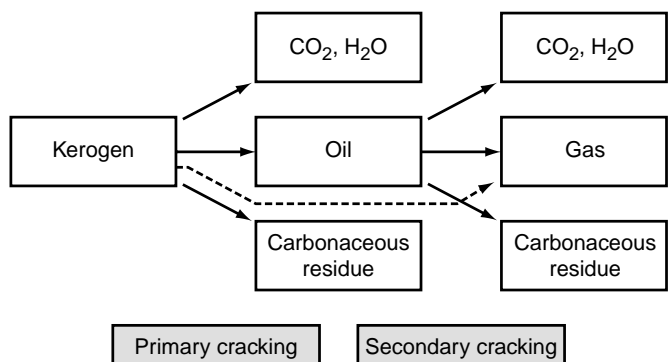
( $\mathrm{n} 1$ reactions) $\quad$ ( $\mathrm{n} 2$ reactions)

Kinetic equation for reaction $i$ $\mathrm{d} X_{i} / \mathrm{d} t=-K_{i} X_{i}$ (first-order kinetics)

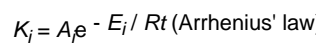

Figure 11
Principles of the formation model of oil and natural gas created by B. Tissot. In Tissot and Welte (1984).

With permission of Éditions Technip.

and subsequently by laboratory experiments as described below. Naturally, a computer was necessary to perform this task, and only the development of data processing from 1965 allowed this to happen. It was also necessary to accurately reconstruct the temperature variations as a function of time in the basins analyzed, for all the sedimentary levels rich in organic matter and consequently forming potential oil source rocks.

All the models used today by the oil companies to predict the location of oil reservoirs in the basins are based on this first model. They serve to calculate the quantities of oil and gas formed in the basins explored over geological time, as well as the changes in the locations of this formation.

\subsection{Engler's Successors}

As a technique for simulating oil formation, pyrolysis earned many disciples following the pioneering work of Engler. The first experiments were conducted in an autoclave with immature sediments rich in organic matter. The products formed were extracted by organic solvents and analyzed by the protocols employed to analyze products found in natural sediments. Subsequently, with the development of gas chromatography, "on-line" analytical techniques were created for products formed from very small samples of sediments during pyrolyses in open or closed media in very small capsules, with or without intermediate condensation in a cold trap, thereby considerably increasing the speed of the operations and varying the experimental conditions. 
These experiments revealed the relationship between laboratory pyrolysis and the formation of oil in the basins. The similarity was so great that an experienced eye could recognize the type and stage of maturation of a kerogen by a simple examination of the distribution of its pyrolysis products.

However, differences also existed: far more resins and asphaltenes were formed in the laboratory experiments than in natural sediments, as well as unsaturated hydrocarbons that were not found in oils. The kerogen also lost its hydrogen too early compared with natural maturation. Pyrolyses in the presence of water produced pyrolysates closer to oils than in the absence of water (Lewan et al., 1979). This led to modeling the reactions, but the interest for pyrolysis as an experimental simulation of oil formation gradually declined.

Yet three fields of application of laboratory pyrolysis became extremely productive: the characterization of the nature and stage of maturation of the source rocks of oil, the study of the structure of kerogens, the calibration of mathematical models of oil formation. Hence the precise simulation of oil formation by pyrolysis was abandoned, as this was impossible, given the very different temperature and time ranges in which the two processes take place, to focus on the plotting of correspondence charts between the natural processes of oil formation and the parameters obtained by pyrolysis.

- The first route included the creation of the "fixed carbon" method by Gransch and Eisma (1970) in the Shell laboratory in Holland, to characterize the stage reached by a kerogen in the oil formation process: the idea was to measure the carbon present in the kerogen analyzed before and after pyrolysis in standard conditions. Clearly the more a kerogen has produced oil in nature the less these two values differ from each other. The ratio of the two values hence decreases towards 1 as the oil is formed, and this ratio can be used to calibrate the advancement of this formation in a basin. This is a more direct method than the method of $\mathrm{D}$. White, which consisted in using the carbon contents of the neighboring coal levels, which do not necessarily exist in the basin.

In 1967, at the Belgian company Pétrofina, Leplat developed a method in which a flame ionization detector was used to measure the quantities of hydrocarbon compounds produced by isothermal pyrolysis in open medium of very small samples of sediments containing organic matter. The quantities of products formed and the form of the pyrograms provided information about the type and quantity of organic matter present and their stage of maturation. Similar researches were also conducted at the USGS by Claypool and Reed (1976).

Bordenave et al. at Compagnie française des pétroles (CFP) in 1970, followed by Larter et al. in 1977 at the Organic Geochemistry Laboratory in Newcastle led by A. Douglas, similarly used a pyrolysis-gas chromatography coupling.
Yet the most complete form of the characterization of the source rocks by pyrolysis resides in the creation at Institut français du pétrole of the Rock-Eval ${ }^{\circledR}$ (Durand and Espitalié, 1975; Espitalié et al., 1977), an instrument that uses pyrolysis at programmed temperature and in open medium of very small samples of ground sediments: the liberation of pyrolysis products is recorded in real time by two detectors, a flame ionization detector which records the production of hydrocarbon compounds, and a thermal conductivity detector which records the production of oxygenated compounds. This makes it possible to rapidly measure the characteristic parameters of the quantity of organic matter present in the samples, its type and its stage of maturation, and thereby to plot logs using rock samples taken by oil boreholes, and yield a measurement of the petroleum potential of the rocks analyzed, i.e. the quantities of oil and gas that they can produce during their burial. It is also possible to transfer the results to geological sections and maps. The automation of this instrument, followed by its coupling with a computer equipped with mathematical models of oil formation, designed to use the parameters gathered and, based on them and the geological data like the history of burial and the thermal history of the samples, allows the historic and geographic reconstruction of oil formation in the basins investigated, and rapidly supplied an indispensable tool for oil exploration. The development and success of the Rock-Eval ${ }^{\circledR}$ were due particularly to Espitalié et al. at IFP.

- The second route was a closer understanding of the chemical structure of kerogens. Thanks to this technique, which supplemented the structural analyses carried out by physical processes, or by the study of extracts of sediments and selected chemical degradation products, the representations of the average structure of the kerogens as a function of their type and degree of maturation were clarified (Behar and Vandenbroucke, 1987). However, these average structures were unpopular with the specialists in molecular geochemistry and the petrographers, because kerogens are not formed of a single entity: they accordingly undertook several projects to identify, in the pyrolysis products, the mark of biological entities participating in the formation of the kerogens. Contrary to coals, in which many biological forms are preserved, these entities are invisible to the optical microscope in most kerogens, which consist essentially of amorphous particles. In some cases, however, bacterial membranes are nonetheless visible to the electron microscope (Largeau et al., 1990). A review of many of these investigations can be found in Rullkötter and Michaelis (1990). These efforts, while they demonstrated the variety of biological entities at the source of the kerogens, failed to establish a quantitative inventory.

- In the third route, the concern was basically to determine the "free" parameters $x i, A_{i}$, and $E_{i}$ of the mathematical 
models of oil formation: in fact, during the exploration of a basin, the data necessary for calibration of the models on the observation of the quantities of oil formed in the sediments are only available late, and these data are largely uncertain. Pyrolysis helps to achieve this calibration by extrapolating the measurements of these parameters made in the laboratory at elevated temperature and with short times to the geological conditions of the formation of oil, i.e. low temperatures and very long times (Ungerer and Pelet, 1987).

\subsection{The Avatars of the Inorganic Theory of Oil Formation}

Despite all these proofs that had been provided of the organic origin of oil, and its confirmation in practice by every day petroleum exploration, the diehards of the inorganic theory persisted. They were generally chemists with very little geological knowledge. The best known belonged to the school of Porfiriev (Sokolov, 1974) in Ukraine: they saw evidence of their theory in the fact that some oil reservoirs exist in nonsedimentary rocks: granitic, metamorphic or porous volcanic rocks. While this was perfectly true, all the studies conducted by geologists had demonstrated that these rocks served as a reservoir for an oil from a sedimentary source rock located not far from there. These "inorganicists" received unexpected support from the American astronomer $\mathrm{T}$. Gold, one of the men responsible for the discovery of quasars. He claimed (Gold, 1979) that natural gas reservoirs resulted from leaks of a primordial methane, i.e. formed at the time of the construction of the earth's first atmosphere and trapped at the time in the depths of the earth's crust, or produced from early bitumens buried at the time. These leaks were favored by earthquakes. The gas could be "polymerized" to form oil as it rose from the depths: in brief, the North Sea oil was formed from gas leaks from the Scandinavian shield. This theory met with some success among mineral geochemists, volcanologists and, in general, with geologists unfamiliar with petroleum. But it had even more success in the media, due to the fantastic nature of this theory, and Gold's relentless proselytism. Petroleum geochemists were taxed with scientific conservatism and placed on the accused bench. They received humiliating memoranda from the administrations, embassies and gas companies. In Europe, a joint meeting was specially organized in Brussels. This was an instructive story on the conditions in which the professions of scientific research are sometimes conducted at the present time.

Finally, T. Gold succeeded in securing funds for a borehole in Sweden in the Lake Siljan region. The choice of this site was dictated by the fact that the lake was installed in an extremely ancient meteoritic crater: the impact of the meteorite was presumed to have fractured the rocks at depth, producing a reservoir with gas rising from the depths. The borehole was naturally a failure (Jeffrey and Kaplan, 1988).

\subsection{The Mysteries of Primary Oil Migration}

While the mechanisms of oil formation were now well understood and modeled, the same did not apply to the mechanisms oil accumulation in reservoirs. Since T.S. Hunt, it was known that these accumulations were preferably found in the anticlinal zones of the sedimentary basins. This was primarily explained by the immiscibility of oil with water: for this reason, in the subsoil, oil was at a separate phase from water which, as we know, is omnipresent in the pores of sedimentary rocks because they are deposited in an aqueous environment. This phase having a specific gravity generally ranging from 0.7 to 0.9 , it underwent a buoyancy force which pushed it towards the higher points. The anticlinal structures played the role of a collector and accumulator, as done by a lake for surface runoff. Where the sediment water was in motion, it could sometimes undergo a hydrodynamic thrust in the direction of the water movement. A movement of the oil was opposed by the capillary pressure applying between fluid phases in the porous media, a pressure which is greater as the pores are smaller. In consequence, an oil phase could circulate in the sediments if the thrust exerted on this phase was greater than the capillary pressure. This explained why rocks with very small pores such as shales, had the capacity of stopping the oil in its general upward movement, and why its circulation in the subsoil could only take place in coarse grained rocks, hence exhibiting high permeability, or in fractures and faults. All this had been formalized in 1953 by the American hydrogeologist M.K. Hubbert and updated in 1973 by the French hydrogeologist A. Chiarelli at SNEA, among others. The travel of the oil from its source rock to its reservoir rock, sometimes several hundred kilometers away, was therefore understood and modelizable.

The expulsion of the oil from its source rocks, called primary migration, as opposed to secondary migration, which is the flow of the oil in the drains, nonetheless remained a mysterious occurrence: it was found that oil source rocks were extremely fine-grained rocks, chiefly shales and marls, because the sedimentary organic matter, as we shall show further on, can only accumulate significantly in this type of rock. Hence the oil could not be formed in the coarse grained rocks in which it flowed and accumulated. But in this case, how could the oil formed in a very fine-grained rock be expelled from it since this rock was presumed to immobilize it due to the enormous capillary pressures presumed to reign between water and oil? Many tests were conducted to try to demonstrate that the oil was sufficiently soluble in the water to be expelled at the same time as the water during compaction of the sediments, or have the ability to diffuse in the water of their pores. These attempts all failed. Solubility measurements of hydrocarbons in water (McAuliffe, 1966, 1980) and diffusion coefficients in water saturated clays (Leythaeuser et al., 1982; Krooss, 1986) finally showed that only methane, ethane and benzene could be expelled this way 
(1)
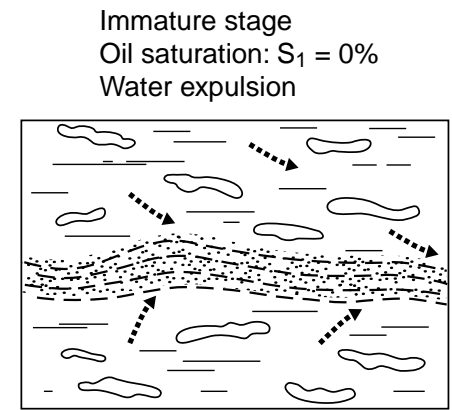

Beginning of oil formation

Oil saturation: $\mathrm{S}_{2}=5 \%$

(2) Hydrocarbons start to invade the porous medium, but no oil expulsion

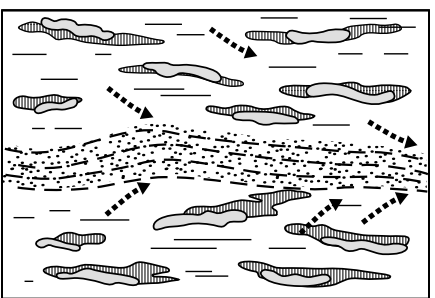

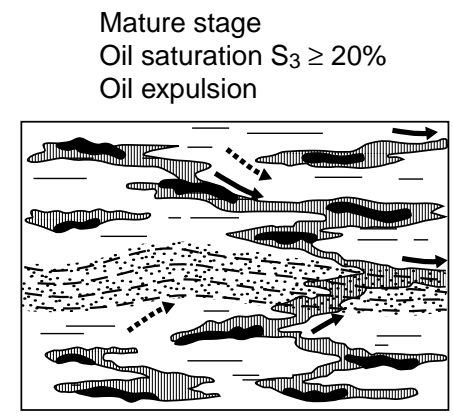
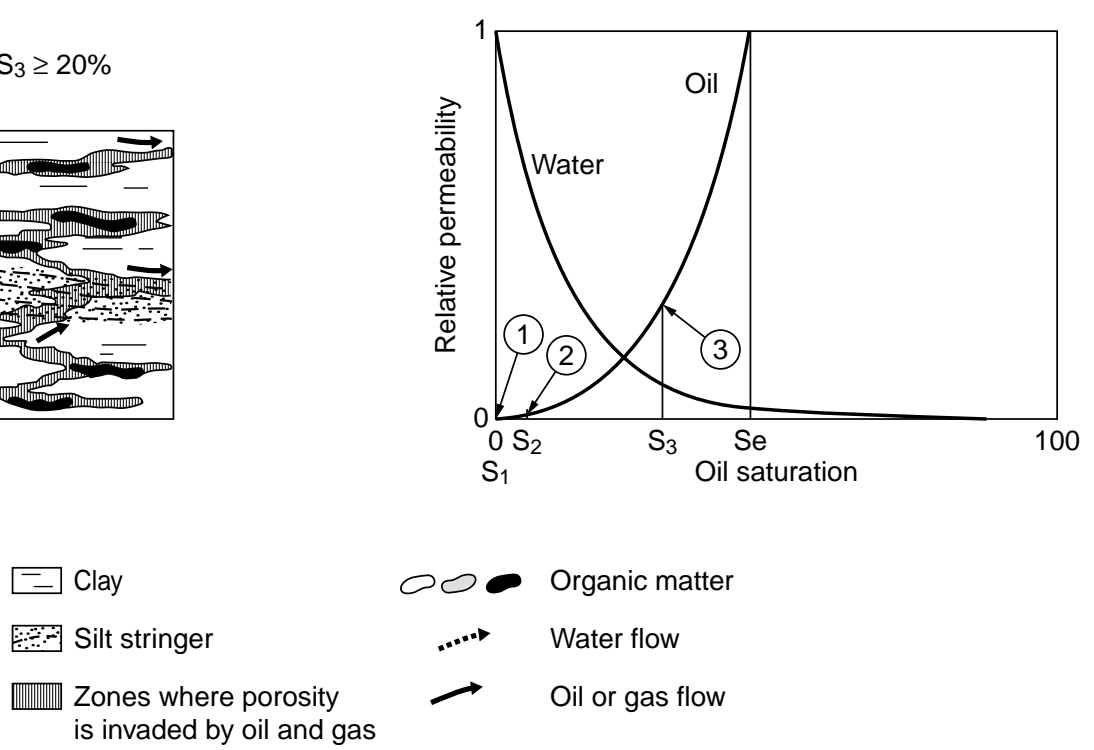

Figure 12

Sketch describing the mechanism of oil and gas expulsion from their source rock: 1) during diagenesis, no oil or gas is produced in the source rocks; the porewater is expelled by compaction; 2) at the start of catagenesis, not enough oil is formed to produce a continuous network in the source rock. The capillary pressure prevents its expulsion, but water continues to be expelled; 3 ) once an oil network is formed in the source rock, the oil starts to be expelled. An oil saturation threshold in the pores of the source rock must be reached, expressed by the curves of permeability to oil and water in the inset. After Ungerer (1993), in Bordenave et al. (1993).

With permission of Éditions Technip.

in appreciable quantities from the source rocks. Besides, the hydrocarbon distribution in the reservoirs absolutely failed to correspond to that which their solubility would have dictated, and the observation and modeling of oil formation showed that this formation took place at depths where compaction had already expelled from the source rocks most of the water that they initially contained.

It was therefore necessary to conclude that the expulsion of oil took place in a separate phase from water. But how, since considerable capillary forces existed in the source rock opposing its movement?

This dilemma was resolved by Ph. Ungerer at Institut français du pétrole. The diagram in Figure 12 shows how he claims expulsion takes place: the source rock, which originally contains an immature kerogen, is progressively buried and exposed to increasing temperature and geostatic pressure. The pressure in the more porous and permeable rocks surrounding it is hydrostatic, which means that the pressure in the pore fluids of the source rock can, if they are expelled, reach up to 2.5 times the pressure of the fluids in the pores of the drains. As long as the kerogen is in the immature zone, there is no oil in the pores of the source rock. Since the pressure in the source rock pores is higher than the pressure in the pores of the surrounding rocks, the water they contain flows into the neighboring permeable rocks, which play the role of drains, and the volume of the source rock therefore decreases. 
Since the depth continues to increase, oil begins to form in the source rock, but not sufficiently to form a continuous phase. Hence the capillary pressure opposes its expulsion. The water continues to be expelled. In a final stage, most of the water having been expelled and the oil having finally formed a continuous phase in the source rock or at least in certain portions thereof, no capillary forces exist opposing the expulsion of the oil, and it is finally expelled from the source rock by the excess pressure of fluid over the surrounding permeable rock. Clearly the oil is expelled later after its formation as the organic matter of the source rock is lower.

These mechanisms have the advantage of being mathematically formalizable by equations of two-phase flow and the concept of relative permeability of the water and oil, as currently used in oil production modeling. An oil saturation threshold had to be reached in the source rock pores for expulsion to take place. The first mathematical model coupling oil formation and migration was then created and presented for the first time at the $11^{\text {th }}$ World Petroleum Congress in London (Durand et al., 1984). Its principles provided the basis for all the models that were subsequently developed by the oil companies.

Progress in modeling oil formation soon helped to determine not only the quantities of oil formed during maturation, but also its composition. It then became possible to model interferences between oil formation and its expulsion from the source rock: clearly the greater or lesser effectiveness of expulsion governs the residence time of the oil that is formed in the source rock. If expulsion is very easy, the system is open and most of the oil formed is found in the drains as it is formed; if expulsion is very difficult, the system approaches a closed system: the oil formed remains longer in the source rock: as the temperature and/or time increase, the oil is cracked into lighter products before being expelled (Ungerer et al., 1988).

\subsection{The Creation of Organic Petrology}

At the beginning was palynology and coal petrography!

Palynology etymologically means science of dust: its object is to inventory the microscopic organic debris observable in the rocks and, inter alia, the spores and pollens which are excellent markers of climates and fossil environments. This is why it is widely used in archeology and sedimentology. It is part of the routine panoply of the sedimentologists who investigate the rocks crossed by petroleum boreholes.

Palynology became important for organic geochemistry following the work of Combaz (1964) at Compagnie française des pétroles, of Gutjahr (1966) at Shell, and of Correia (1967) at Institut français du pétrole.

The first used a microscope to observe, in organic debris isolated from sedimentary rocks after the destruction of their minerals (by hydrochloric acid for carbonates and by hydrofluoric acid for silicates), regularities in proportions of the different components: spores, pollens, wood fragments, plant cells, amorphous organic matter which is the majority component in most cases but which may have widely varying appearances: floc, granular, film, etc. (Combaz, 1980). He called palynofacies the diagram of the proportions of the different components. This palynofacies is a signature of the sedimentary formations crossed in drilling and can therefore serve, inter alia, to correlate these formations together. To some extent, it is also possible to approximate the petroleum potential of the organic matter present. For example, an organic matter very rich in higher plant debris very probably contains a type 3 kerogen, hence with low petroleum potential.

The latter two, by observing spores and pollens isolated from samples of sediments from petroleum basins, found a progressive blackening of them with depth, and identified classes of increasing coloration which they then compared with the location of the fields. They demonstrated the existence of a correlation between these classes and the steps of oil formation. This approach followed the same principle as those of D. White and M. Teichmüller.

These methods were soon used systematically and improved in the oil companies. A number of coal petrographers then took an interest in oil. We have already mentioned the work of M. Teichmüller at the Krefeld Research Center in Germany. From 1965, steady cooperation was established between certain coal petrographers and petroleum geochemists, leading to the emergence of a synthetic discipline, organic petrography, which includes all microscopic methods of investigation of rock organic matter, whether dispersed in the rocks or concentrated as in the case of coals. Pioneers of this organic petrography, apart from M. Teichmüller and her colleagues (Teichmüller, 1986), include B. Alpern at the Charbonnages de France Research Center (CERCHAR) at Creil (Alpern et al., 1972), A. Combaz at CFP, P. Robert at SNEA, P. van Gijzel at the University of Nijmegen in Holland, N.H. Bostick of the Illinois State Geological Survey in the United States, and H. Jacob at the BGR in Germany.

1973 witnessed in the premises of the CNRS in Paris, under the leadership of B. Alpern, a symposium entitled: "Petrography of organic matter of sediments, relations with paleotemperature and petroleum potential", whose title clearly explains the major concerns of the discipline: apart from the need to class the organic material of the rocks as a function of its morphology and origin, the aim was to measure parameters under the microscope connected with the effect of temperature on the organic matter of the rocks and hence the maturation, and parameters allowing an estimate of the quantities of petroleum that this organic matter could produce during its burial, which is called the petroleum potential. The proceedings of this symposium were published in 1975 (Alpern, 1975). 
The International Committee for Coal Petrography (ICCP) then created a "Dispersed Organic Matter (DOM)" commission, in which the organic petrographers presented their work. A rival society, the Organic Petrology Society was created later.

Vitrinite reflectance then became the reference parameter for petroleum geochemists to calibrate the advancement of maturation. Other parameters consequently came into routine use, such as the Thermal Alteration Index (TAI) which measures, following the work of M. Correia, the degree of blackening of organites in relation to the stage of maturation, or measurements of the intensity or color of fluorescence of these organites. Correspondence tables between these parameters and stages of oil formation were proposed.

Maceral analysis, by which the proportions of the different macerals of a kerogen are measured, was used to assess the petroleum potential, and then, for the study of organic matter by reflection microscopy, became the equivalent of the palynofacies for the study by transmission microscopy.

Organic petrography then became an indispensable complement to the physicochemical methods for the analysis of organic matter, because it allowed the observation of the variety and heterogeneity of this matter.

\subsection{Towards a Broad View of Organic Geochemistry: Organic Sedimentology, Biogeochemistry and Organomineral Geochemistry}

The progress of chemical analysis and the overall approach of geological phenomena permitted by the developments of the theory of plate tectonics allowed organic geochemistry in the 1960s to go beyond the relatively narrow framework of the study of fossil fuels. In a broader view, it gradually became a science of chemical interactions between the biosphere, consisting of living organisms and the products of their degradation after their death, and the geosphere. In these interactions, microorganisms play an important role. It is already in this "biogeochemical" form that Verdnasky had imagined organic geochemistry.

Considered in this way, the formation of fossil fuels is a biogeochemical process. This also applies to the formation of coral reefs and stromatolits, the formation of mollusk shells, the precipitation of carbonates in the oceans, the formation of organic soils and sediments, and the concentration of chemical elements that leads to the formation of useful minerals (Disnar and Sureau, 1990). In the latter case, organomineral geochemistry is alluded to rather than biogeochemistry. We shall illustrate the development of this organic geochemistry in the broad sense of the term by the following examples.

\subsubsection{Organic Sedimentology}

Most geologists evidenced very slight interest in the study of sediments containing organic matter for a long time, even after they had realized their importance in the formation of oil. Some exceptions were D. White and H. Potonié, who tried in the early $20^{\text {th }}$ century to understand how peats were formed and to identify the factors responsible for their variety. Potonié in 1908 coined the term sapropel for muds rich in organic matter formed in reducing environments.

Also noteworthy is the work of Trask and Patnode (1942), who used the resources of their time to analyze a large number of sediments rich in organic matter, and later on, the work of Hunt $(1963,1972)$.

However, all of this failed to create a genuine organic sedimentology, in other words, the study of the logic of distribution in time and space of the sediments rich in organic matter.

An important step in this direction was made by the oceanographers, who started by measuring the organic carbon content of recent sediments and relating them to the productivity of surface waters for phytoplankton and the physiography of the sedimentary environments. In France, a pioneer was J. Debyser, a pupil of Bourcart, who was an oceanographer with an interest in depositional modes of marine muds. J. Debyser in 1959 presented his thesis on the geochemistry of marine muds. He was also one of the promotors of the creation of the organic geochemistry department of IFP.

After this, Datsko (1959, 1961), Pakhomova (1961), Bordovsky (1965), Calvert and Price (1971), Degens et al. (1971, 1973, 1974), among others, investigated the distribution of organic carbon in sediments of a number of bays and closed seas, the Black Sea, the Caspian Sea, the Bering Sea, Walvis Bay, etc., and related them to the productivity of phytoplankton, the oxygen contents of the water column, the direction of currents, the mineralogy of sediments (Fig. 13) etc. The Russian oceanographer Romankevitch (1977) plotted a map of the organic carbon content of the sediments sampled in all the oceanographic surveys throughout the world and related them with that of the oceanic productivity of plankton previously determined by E.T. Degens and his colleagues. The oceanographers were joined in the 1970 s by organic geochemists, under the pressure of petroleum explorers who wanted to anticipate the presence and extension of organic rich sediments likely to be source rocks for oil, to secure permits in presumably favorable zones of the basins being explored. The organic geochemists had very little experience at the time with recent sediments, but enjoyed access to ancient sediments and, thanks to Rock-Eval ${ }^{\circledR}$, possessed a rapid method of investigation. Some of them adapted the soil analysis methods to the sediments (Brown et al., 1972; Huc and Durand, 1974).

Among the most prominent work of the geochemists was that of the ORGON and MISEDOR research groups (19771983), coordinated by R. Pelet and Y. Debyser of Institut français du pétrole and A. Combaz and J.L. Oudin of 

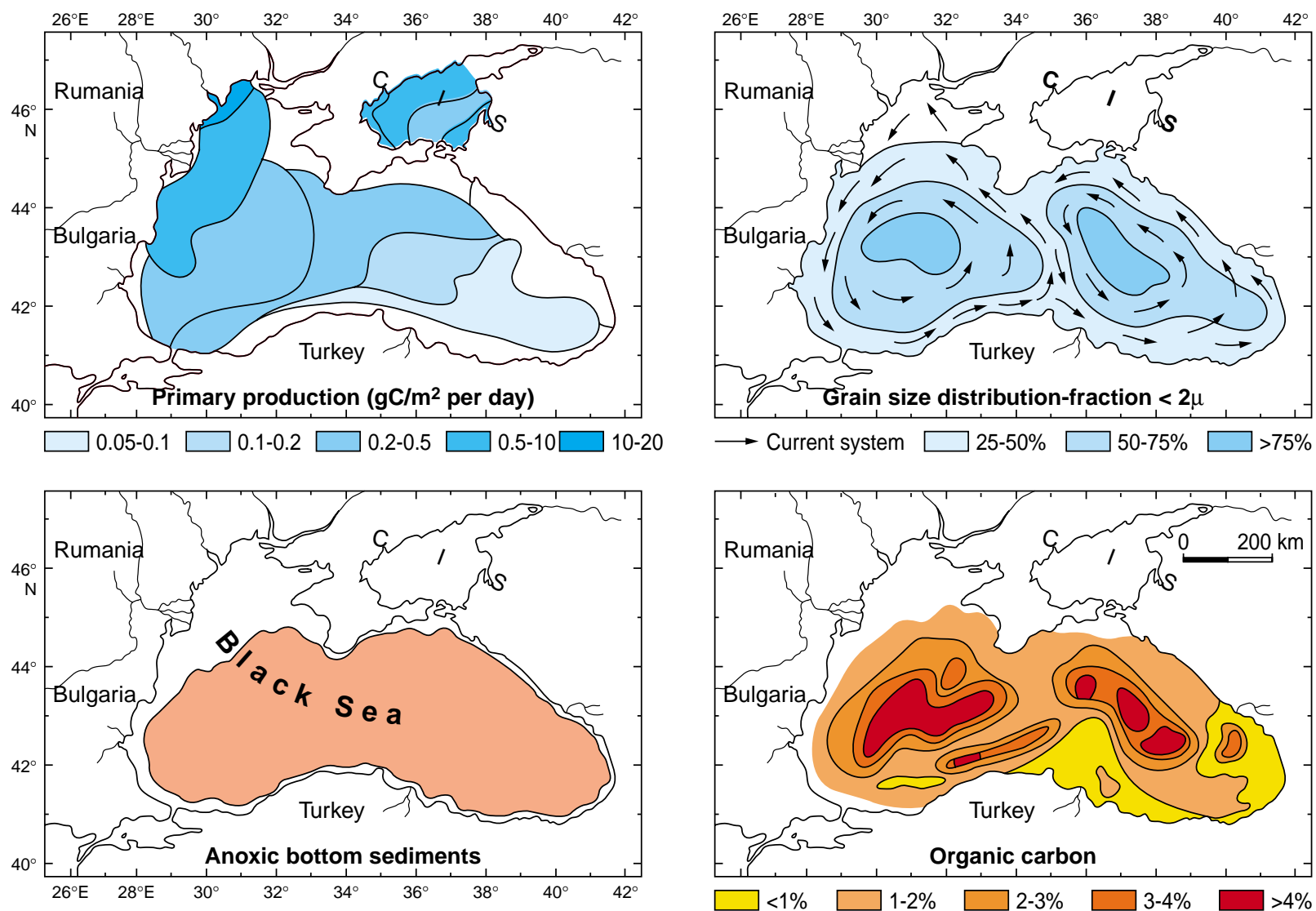

Figure 13

Primary productivity, grain size and organic carbon content of recent sediments, and location of zones where the bottom is currently anoxic in the Black Sea. Document A.Y. Huc after Finenko (1967), Shimkus and Trimonis (1974) and Müller and Stoffers (1974).

Compagnie française des pétroles, which, alongside the researchers of these two institutions, included researchers of several CNRS laboratories. These groups organized ocean surveys designed to analyze the composition of organic matter of recent sediments sampled by cores in sedimentary environments of which the physiography was well known. They also made a microbiological analysis of the sediments.

The DSDP (Deep Sea Drilling Project) and ODP (Ocean Drilling Project) campaigns of the American deep water drill ship Glomar Challenger, although mainly focused on the study of continental drift, allowed the geochemical analysis of organic rich sediments, recent and less recent, at many places of the globe. Also noteworthy was the work of B. Tissot, G. Deroo and J.P. Herbin at IFP and of P.C. de Graciansky at ENS Mines de Paris on the formation of organic matter rich sediments associated with the opening of the North Atlantic (Tissot et al., 1979; de Graciansky et al., 1982).

Then G. Demaison of the US company Chevron formally established the links between the plankton productivity of the water, the oxygen content of the sedimentation environment, the transport distance of organic debris from the surface to the sediment, and the quantity of organic matter preserved in the sediments (Demaison and Moore, 1980). Demaison highlighted the vital role played by anoxia, whether created by the lack of oxygen in the water of the sedimentation environment, or by the abundance of organic debris, in the formation of sediments rich in organic matter. In fact, in anoxic conditions, aerobic microorganisms, those with the most destructive action on organic debris, cannot develop.

It was found that only $1 \%$ on average of the carbon in the biomass annually produced at the surface of the oceans (primary productivity) escaped mineralization to carbon dioxide to be incorporated in the sediments, and that the sediments containing organic matter, future source rocks for oil and natural gas, were very fine-grained sediments, shales or marls; partly because the hydrodynamic properties of organic debris are close to those very fine minerals and because they can adsorb organic molecules, and also, and above all, because the fineness of the grains prevents the water from circulating in the sediment and hence restricts the access of oxygen to the organic matter. 


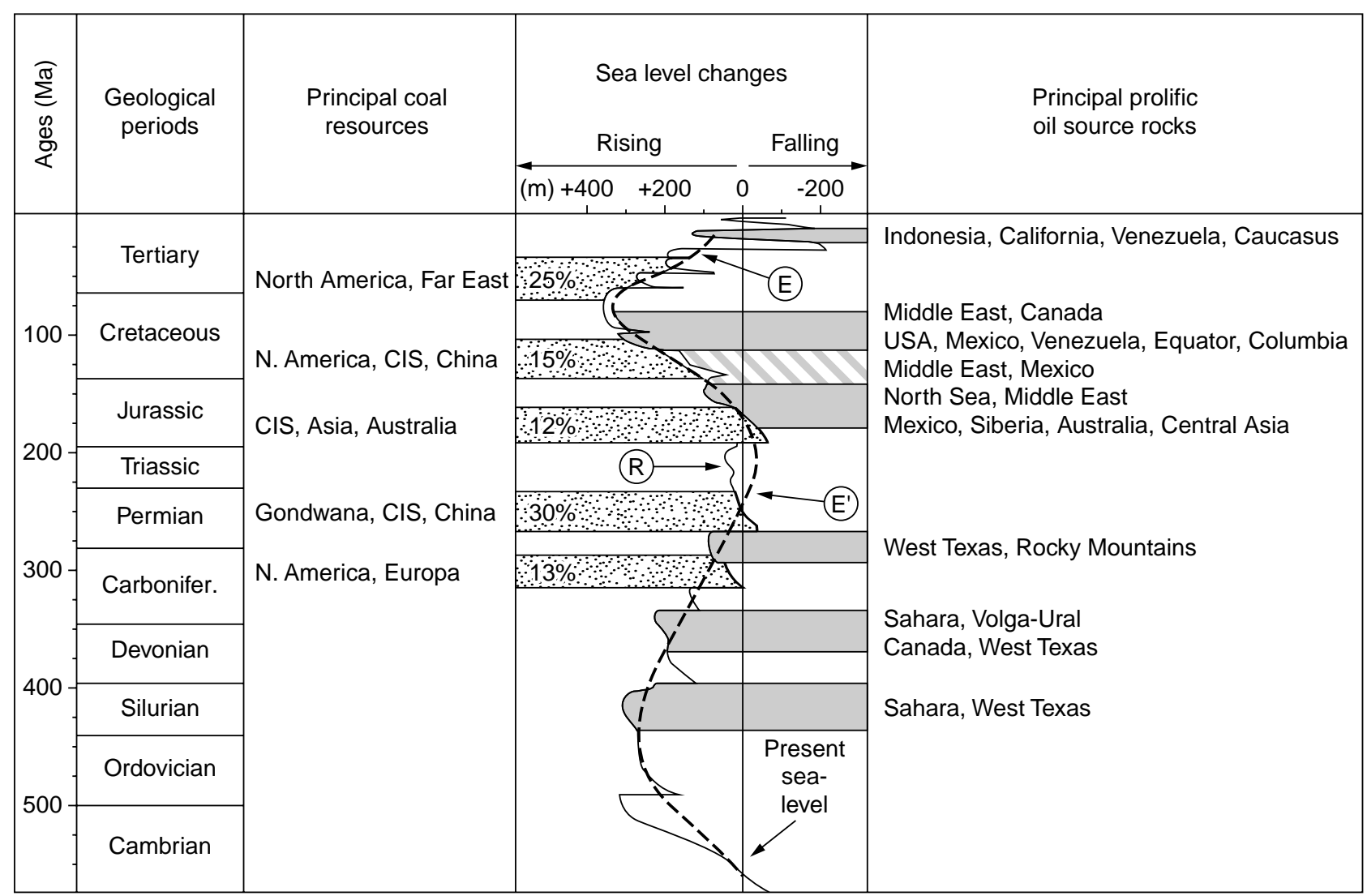

Figure 14

Distribution of the main oil source rocks and main coal series as a function of geological time, related to fluctuations in sea level. After Tissot (1979).

This gave rise to a much more accurate idea of environments favorable to the formation of sediments rich in organic matter, enabling the geologists of the oil companies to anticipate their presence in the basins from paleogeographic findings: these environments are closed seas, bays, lagoons, lakes, where the access of oxygen to the sedimentation environment is restricted, and coastal zones with upwelling. River deltas installed in areas of abundant vegetation are also very favorable environments, because the very abundant plant debris is quickly buried and therefore escapes the action of aerobic bacteria. The reference types of kerogen corresponded to three different types of sedimentation: evaporitic lacustrine environment for type 1 , anoxic marine environment for type 2, deltaic or detrital coastal environment for type 3.

It was finally recognized that certain geological eras were much more favorable than others to the formation of organic matter rich sediments, which obviously have consequences on the distribution of oil and coal: in particular, the periods of the great transgressions, because they caused the formation of shallow closed seas where anoxic conditions were easily created, were favorable to the existence of source rocks for type 1 or 2 kerogen, potentially the most productive for oil; while the periods of the great regressions, during which detrital sedimentation developed, were favorable to the formation of coal (Tissot, 1979, Fig. 14), Bois et al. (1982).

\subsubsection{Sedimentary Microbiology}

Microorganisms were found to play a major role not in the formation of oil as believed by ZoBell, but in that of organic sediments for oil, and in the degradation of oils.

Bacterial debris can form an important share of the kerogen. This is the case for example of type 1, largely formed of membranes of bacteria which developed on debris of lacustrine algae. Aerobic microorganisms are highly active in the destruction of organic debris, which are mineralized into carbon dioxide. Methanogenic bacteria develop in sedimentary environments devoid of oxygen, sulfates and nitrates, and produce methane $\left(\mathrm{CH}_{4}\right)$. This methane, whose 


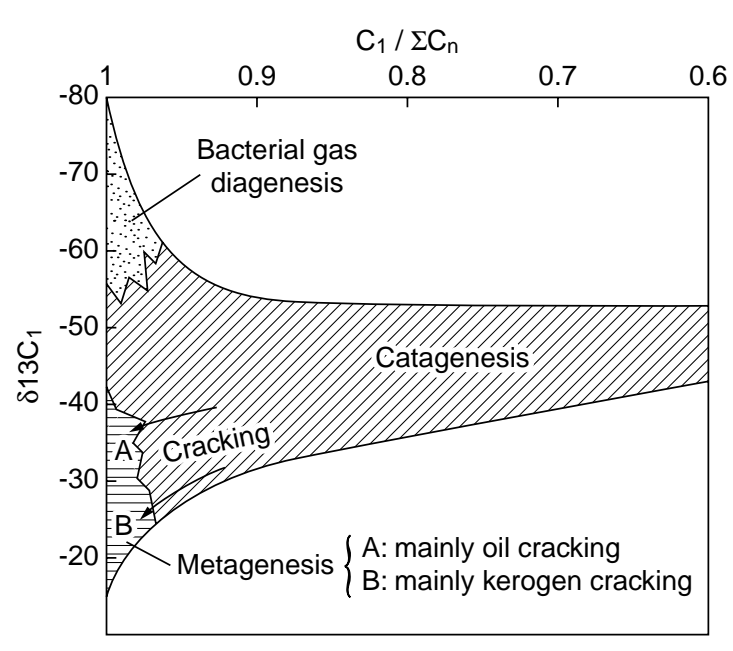

Figure 15

Situation of bacterial gas and thermal gas in a diagram where the proportions of methane in the gaseous hydrocarbons in the $x$-axis and the $\delta{ }^{13} \mathrm{C}$ of methane carbon on the $y$-axis. The bacterial gas is characterized by a very negative $\delta{ }^{13} \mathrm{C}$ and the absence of gaseous hydrocarbons other than methane (after Tissot and Bessereau, 1982; Tissot and Welte, 1984).

With permission of Springer-Verlag.

formation mode is similar to that of biogas produced by anaerobic fermentation of organic waste, is according to Rice and Claypool (1981), making up to $20 \%$ of the gas fields, and according to Matavelli and Novelli (1988), it even forms most of the gas found in Italy. This "bacterial" gas (Vially et al., 1992) also called "biogenic" gas, is distinguished from the "thermal" gas formed by the maturation of kerogen by the absence of other hydrocarbons than methane, and by a smaller $C_{13}$ content of the carbon in the methane $\left(\delta^{13} \mathrm{C}\right.$ much more negative) (Fig. 15).

Sulfate reducing bacteria, which develop in sulfate rich highly reducing environments, have the property of producing hydrogen sulfide: in detrital environments rich in iron, these can combine with the iron to form hydrotroilite which is rapidly converted to pyrite. This mineral is embarrassing for the coal industry because it liberates sulfur dioxide during its combustion. This gas represents the source of acid rain, which has acidified the lake waters in northern Europe and which has, probably wrongly, been blamed for the destruction of the forests in these regions. In calcareous environments poor in iron, hydrogen sulfide combines with organic matter to yield sulfur rich kerogens, which during their maturation produce sulfur containing oils unpopular with refiners.

Microorganisms have the capacity to degrade oils in their reservoirs (Evans et al., 1971; Deroo et al., 1974; Connan, 1984), to the point where 20 to $30 \%$ of the oils have thus been degraded at one time or another in their history. They are also capable of degrading the oil spread during the spills as well as fuels stored in precarious conditions. These microorganisms are still insufficiently known at the present time.

It was recently suggested that about half of the earth's biomass could be found in the form of microorganisms present in sediments. Hence a great deal still needs to be done in sedimentary microbiology.

\subsubsection{Two Examples of Organomineral Geochemistry: Thermosulfate Reduction and the Formation of Uranium Deposits}

Thermosulfate reduction is the reduction of the sulfates present in evaporated sediments by hydrocarbons, as soon as the temperature reaches about 100 to $150^{\circ} \mathrm{C}$. Hence the process takes place at great depth in reservoirs where the reservoir rock contains sulfates. The reduction of sulfates produces carbon dioxide and hydrogen sulfide. Since the reservoir rocks of this type are generally carbonates or dolomites which contain no iron, the hydrogen sulfide cannot form pyrite and remains stable. These reservoirs hence contain large proportions of hydrogen sulfide. Some examples are the Lacq reservoir and the reservoirs of the north of the Caspian Sea. It is still difficult to describe this process other than qualitatively (Goldstein and Aizenshtat, 1994).

The formation of uranium minerals owes a great deal to organic matter (Landais et al., 1990; Oh et al., 1990), which acts specifically in two ways in the concentration of uranium:

- "Passively" by creating reducing conditions to facilitate the precipitation of uranium, which is known to be soluble in oxidizing medium and insoluble in reducing medium. For example, petroleum explorers are fully aware that certain organic sediments, like the Kimmeridge-clays in the North Sea and the Silurian clays in the Sahara can be identified easily by $\gamma$-ray probe because they contain significant amounts of uranium. Wireline loggers have not hesitated to generalize this observation by recommending the use of this probe to detect formations rich in organic matter. However, the presence of uranium also depends on the uranium supply by the leaching of an emerged granitic formation located nearby during sedimentation, which is not the general case. This process, however, is the origin of many uranium deposits.

- "Actively" by its adsorption and chelation properties with respect to certain metals, and particularly uranium.

\subsubsection{The Dustbins of Geological History and the Evolution of Living Beings}

The chemical structure of the biomarkers found in sediments and oils is, as we have seen, related to that of the functional molecules of organisms, and, by digging the dustbins of geological history, it is possible somehow to track the evolution and activity of living beings. 
Thus for example, biochemists have explored and identified hopanoids in living beings after they were found in sediments (Ourisson et al., 1979), and a marker of the appearance of flower plants, $18 \alpha(\mathrm{H})$-Oleanane, was identified in the tertiary sediments of the Niger delta (Ekweozor et al., 1979). McKirdy et al. in 1983 identified markers of the organisms of the time in pre-Ordovician oils. This aspect was also illustrated by Seifert and Moldowan (1981) and by Reed et al. (1986). It deserves further development.

A much longer list could be compiled of the study topics of this organic geochemistry in the broad sense of the term, and the lack of a greater concentration of research resources in this field at the present time is to be regretted.

The period of expansion of organic geochemistry also saw the emergence of a number of reference works: in 1978 Petroleum Formation and Occurrence by B. Tissot and D.H. Welte, a book that played a considerable role in the development of organic geochemistry, in 1979 Petroleum Geochemistry and Geology by J.M. Hunt, in 1980 Kerogen, Insoluble Organic Matter of Sedimentary Rocks, by B. Durand et al. and in 1985 Geochemistry in Petroleum Exploration by D. Waples.

\section{5 - MATURITY AND INTEGRATION}

In 1985, all the major oil companies, including the national companies of the leading producing countries, had organic geochemistry laboratories, and the teams were often trained in the pioneer laboratories. Laboratories were also found in the public research institutions dedicated to fossil fuels just about everywhere. At the Petroleum Congress, R.J. Murris of Shell made a flattering assessment of the impact of organic geochemistry on exploration results. The Afro-Asian Society of Organic Geochemistry was created at Dehra Dun in India in 1986, and the Latin American Society of Organic Geochemistry was formed in 1988 at Rio de Janeiro in Brazil.

1989 saw the $14^{\text {th }}$ International Meeting on Organic Geochemistry at the Maison de la Chimie in Paris. It gathered together 560 participants, a historic record. Half of the proceedings of this congress was devoted to petroleum geochemistry alone, and the remainder to other subjects, mainly molecular geochemistry, as well as organic sedimentolgy, structure of kerogens, geochemistry of organic sulfur, organomineral geochemistry, isotopic analysis, and analytical techniques.

Books were published such as the Applied Organic Geochemistry by Bordenave et al. (1993), Organic Geochemistry, Principles and Applications by Engel and Macko (1993), Petroleum and Basin Evolution. Insights from Petroleum Geochemistry, Geology and Basin Modelling by Welte et al. (1997) and works on biomarkers and their use (Connan, 1987; Moldowan et al., 1992; Peters and Moldowan, 1993).

\subsection{Petroleum Systems and Basin Simulators}

The 1990s witnessed the triumph of the concept of the petroleum system among petroleum explorers, a concept dating back to the 1970s, but only formalized much later by G.J. Demaison (Demaison, 1984; Demaison and Huizinga, 1991).

In this concept, the basins are considered as immense physicochemical reactors, which change slowly during geological history; they contain one or more petroleum systems consisting of a source rock, reservoirs, drains allowing the circulation of oil from the source rock to the reservoir (permeable sediments such as sandstones and coarse grain limestones, faults) and permeability barriers (impermeable sediments such as shales and evaporites, fault closures). The presence of oil in a reservoir is the result of a whole sequence of more or less probable events spreading over time intervals from several tens to several hundred millions of years. This sequence includes:

- deposition of a sediment rich in organic matter;

- burial of this sediment in thermal conditions allowing maturation of the organic matter that is adequate for the formation of oil and gas;

- migration and accumulation, thanks to the existence of a system of drains, of the oil and gas formed towards structures permitting their reception (traps);

- preservation of the oil and gas accumulated in these structures (good tightness of the permeability barriers, absence of biodegradation).

The absence of a link in the chain makes the system inoperative. The "load" of these petroleum systems consists of the oil and gas produced by maturation of the kerogens present in the source rocks, and varies considerably according to the systems. The "impedance" of the petroleum systems is the resistance of the sedimentary layers to the circulation of the oil; it also varies widely from one system to another. The petroleum interest of a sedimentary basin can be assessed from the geological parameters with respect to known petroleum systems and also by the product of the probabilities of existence of each of the links in the chain.

The quantification of the functioning of petroleum systems during their geological history, and hence the location of the basin areas that are most favorable to the accumulation of oil, can be formed using "basin simulators", which offer a deterministic computer simulation of the entire sequence of events.

Such simulators were developed in particular at IFP by Ungerer et al. (1990), Burrus (1997) and Schneider et al. (2000) and at the KFA in Jülich in Germany under the direction of $\mathrm{D}$. Welte. The oil majors also developed their own tools, first with the help of the above two groups.

The construction and application of these models, comparable in size to meteorological models, demands 
outstanding computer engineering and the availability of very powerful computers. They also demand the availability of geological and physical data that are as numerous and accurate as possible, whereof the consistency can be checked by the model. Hence basin models are a powerful incentive to construct high quality databases in the companies. They are also a powerful incentive to research in relatively unknown areas, such as the thermicity of sedimentary basins, as the thermal regime closely conditions the rate of oil formation.

These simulators are also places for the integration of a large number of disciplines. Petroleum geochemists are therefore only one of the parties involved. One of their specific roles is to supply the most accurate possible parameters of the kinetics of oil formation. To escape the uncertainties and slowness of methods for validating kinetic models by using measurements on samples, they had already developed methods to calculate kinetic parameters from laboratory experiments (Ungerer and Pelet, 1987). These methods saw considerable development and became increasingly accurate (Béhar et al., 1997). They were also expected to provide a

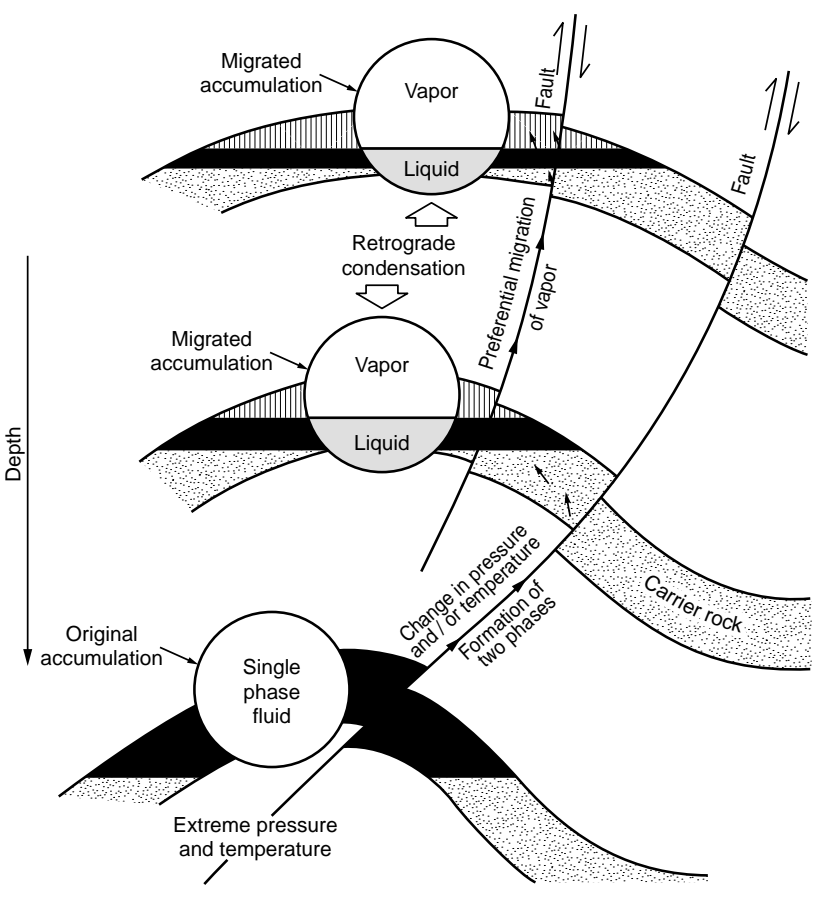

Figure 16

Sketch showing an example of multiphase behavior of hydrocarbons during their rise to the surface. The initial accumulation is single-phase because of the high temperatures and pressures at depth. The hydrocarbons escape this initial reservoir and join another structure where they form a two-phase reservoir due to decreases in temperature and pressure, etc. In Tissot and Welte (1984) after Silverman (1965).

With permission of Springer-Verlag. number of controls by "field" measurements such as that of the composition of the oil and organic matter in the sediments, and of the maturation parameters.

While oil migration was understood in its main features, must work still needed to be done to fully transcribe the mechanisms into a basin simulator. One of the major problems is to take account of the often multiphase character of the movement of petroleum fluids in the sediments. In fact, part of the oil formed in the source rocks, primarily resins and asphaltenes, remains there in a solid or adsorbed state. The mobile portion can form one or more "oil", "gas", or "bitumen" phases in the pores of the drains and reservoirs, depending on its composition, the local thermodynamic conditions and the residence time in these thermodynamic conditions. These processes, previously investigated by Silverman (1965), (Fig. 16), Nogaret (1983) and Ungerer et al. (1983, 1988), among others, have to be "attuned" throughout the migration paths from the source rock to the reservoirs. The inclusion of this "geochemical thermodynamic" is a particularly difficult task, which is not yet fully achieved at the present time.

\subsection{Sequential Stratigraphy and Organic Sedimentology}

In the 1990s, interest in the organic aspects of sedimentology grew among sedimentologists, as part of a general framework of the questioning of the methods of sedimentology, initiated by the work of P. Vail of Exxon, which led to a renaissance of sequential stratigraphy. This consists in predicting, at a given place, the type, succession and extension of sedimentary deposits as a function of the type and scale of the inputs, the nature of the transport mechanisms, and the space available at any time to receive the sediments (accommodation). This space is itself a function of the subsidence of the basin, the compaction rate of the sediments, and fluctuations in sea level (eustatism). Renewed interest in organic sedimentology also emerged among oceanographers and climatologists for the reconstruction of ancient climates and geographys, in view of the relations existing between paleogeography, paleoclimates and the preservation of organic matter in the sediments. The major contributions to these researches included J. Parrish, E. Barron and W. Hay in the United States (Huc, 1995).

Several important works on organic sedimentology were published: Petroleum Source Rocks by Katz (1995), and special publications of the major petroleum journals: $A A P G$ Studies in Geology no. 37 Source Rocks in a Sequence Stratigraphic Framework published by Katz and Pratt (1993), the AAPG Studies in Geology no. 40 Paleogeography, Paleoclimate, and Source Rocks published by Huc (1995) and the SEPM Special Publication no. 60 Mesozoic and Cenozoic Sequence Stratigraphic of European Basins by de Gracianski et al. (1998). 
It became possible to clarify the paleogeography and the quantitative importance of the sediments with organic matter at different geological times (Klemme and Ulmishek, 1991). The most favorable were the Silurian, the Upper DevonianLower-Carboniferous sequence, the Upper-CarboniferousLower-Permian sequence, the Upper Jurassic, the Middle Cretaceous and the Oligocene-Miocene. At a smaller scale, relations between climatic cycles, variations in sea level and deposits of organic matter were identified, and precise correlations between levels rich in organic matter were made at the scale of the sedimentary basins (G. Bessereau et al., 1995; van Buchem et al., 1995; B. Duval et al., 1998; among others).

\subsection{The Decline of Petroleum Exploration}

In the 1990s, discoveries of major fields became rare. Then the sudden drop in the price of oil in 1998 led the oil companies to reorganize to contend with a low price per barrel. This was the time of the mergers and acquisitions. Despite the strategic importance for the companies of the renewal of their reserves, they progressively focused on production and made swingeing cuts in exploration. Most of the organic geochemistry laboratories were closed down. In the remaining laboratories, the staff was reduced and the work almost exclusively focused on service activities for subsidiaries.

Yet new topics emerged almost immediately in petroleum exploration:

- After long years of a nearly total disinterest, particularly due to the cost of its transport, natural gas very quickly became an energy source competing with oil. In fact, the development of cogeneration techniques with gas helped to obtain very high energy efficiencies in power generation, and gas demand grew sharply. Its flexibility of use and less pollutant combustion than that of oil also favored it.

- Following the opening to international companies of a number of major producing countries, the western companies explored new regions, such as the basins of the Caspian Sea.

- Following the discoveries of large deep sea reservoirs off the Gulf of Guinea and Gulf of Mexico, specific deep offshore exploration was developed.

- Following the discovery of oil reservoirs in the deep zones of certain basins where high pressures and high temperatures prevailed, whereas gas was expected to be found, these zones aroused renewed interest in exploration.

Petroleum geochemistry adapted to this new situation by developing specific researches on these topics. At Institut français du pétrole, this included the work of Prinzhofer and Huc (1995) and Prinzhofer et al. (2000) on the geochemistry of hydrocarbon and non-hydrocarbon gases, the work of Huc et al. (2001) on deep offshore organic sedimentation, and the work of the modeling group on basin modeling in high temperature and high pressure zones.
It went also beyond its traditional field, exploration, to develop a production geochemistry, in which the priority topics are the identification of the different compartments in the same reservoir (England, 1990; Smalley and England, 1992; Kaufman et al., 1990), the location of asphaltic levels (Huc et al., 1999), and the study of biodegradation mechanisms. These studies were aimed to facilitate the recovery of the oil present in the reservoirs.

Petroleum geochemistry also developed into the field of the detection and remediation of soils polluted by hydrocarbons.

\section{CONCLUSIONS}

Organic geochemistry is a very young field compared to most other sciences. Its history has only lasted two to three generations of researchers for the time being. It is therefore possible at one glance to encompass the conditions in which it was created and developed.

It is to petroleum, particularly to petroleum exploration, that it owes its birth and its main development. It is therefore economic demand and not a search for basic knowledge that was the main drive of its creation. It is the rational observation of nature, more than theoretical developments, which played a decisive role in the understanding of the mechanisms of oil formation. The spectacular expansion of the technology of analytical methods since 1960 (separation techniques, elementary analysis, gas chromatography, all sorts of spectrometric methods, GC-MS coupling) played a vital role by allowing the separation and identification of a large number of molecules and characterization of complex products. The development of data processing helped to manage the abundance of data thus gathered, to construct models and to apply them to concrete cases.

It was observed that many researchers who had been interested in the origin of oil and the mechanisms of its formation were confused because they remained imprisoned by the knowledge and ways of thought of their discipline and their specialty: chemists against geologists (and even "chemist" geochemists against "geological" geochemists) specialists in coal, oil shales, of upstream and downstream petroleum operations.

It is the researchers of the industry or close to the industry rather than university researchers who were responsible for the shaping of organic geochemistry. This is no doubt largely explained by the fact that university teams, unless they have created links with the industry, rarely had the essential samples and geological documents. We also find that the university system, organized into small teams specialized and put in competition within the same discipline, does not foster multidisciplinarity. This is better organized in industry, where work is done by project rather than by specialty. University geologists, much more than university chemists 
who have made considerable achievements in molecular geochemistry, were absent to this adventure. It is also observed that at the present time, organic geochemistry is still only rarely taught in geology departments, despite the scale of the documentation available today.

Even more than those of the oil companies, the research teams of the large professional institutions were responsible for the main breakthroughs, as was also the case for coal science. This is partly explained by their capacity to mobilize a sufficient number of researchers on a project and to understand industrial concerns, and also by the time they had in comparison with the oil company researchers who had immediate and operational concerns. This probably explains the preponderance of Europe, with its numerous institutes, in the development of organic geochemistry from 1960. Among these institutes, Institut français du pétrole at RueilMalmaison (IFP) and Kernforschungsanlage (KFA) at Jülich in Germany, were particularly active and productive. And if we only mention two names among the great founders and leaders of organic geochemistry, they are certainly those of B. Tissot, who created the organic geochemistry department of IFP, and D. Welte, creator of the Institut für Erdöl und Organische Geochimie of the KFA.

Organic chemistry was born of oil and will perhaps disappear with it. But it still has a fine season ahead of it.

The death of oil has been announced, but not before the end of the century. It will first be necessary to maintain an exploration effort to delay the inevitable hegemony of the Middle East and this effort will be made in increasingly difficult conditions. Petroleum geochemistry in this framework will be more than ever useful for economizing very costly drilling operations. The knowhow acquired will then have to be transposed to the prospects of the Middle East, which is an underexplored region. Production geochemistry will also be to some extent the successor of exploration geochemistry.

Heavy oil, tar sands, oil shales and coals will by the end of the century make up for most of the remaining reserves of fossil fuels. Organic geochemistry can play a role in their utilization, if they still turn out to be competitive with the other forms of energy.

Organic geochemistry in the broad sense of the term: organic sedimentology, sediment microbiology, molecular geochemistry, organomineral geochemistry, etc. is bound for major developments. It is important to secure a better understanding of climatic processes, of what happens to anthropic pollutants in the water, soil and sediments, of the evolution of living beings. The long term future of organic geochemistry probably lies in the contribution to the resolution of these highly complex problems, in which a geological as well as chemical view is too little emphasized for the time being, and the drivers of this research will be the growing concern for the environment and, we hope, the taste for knowledge.

\section{REFERENCES}

Abelson, P.P. (1963) Organic Geochemistry and the Formation of Petroleum. 6 th World Petr. Cong. Proc., 1, 397-407.

Albrecht, P. and Ourisson, G. (1969) Diagenèse des hydrocarbures saturés dans une série sédimentaire épaisse (Douala, Cameroun). Geoch. Cosmochim. Act., 33, 138-142.

Albrecht, P. and Ourisson, G. (1971) Biogenic substances in sediments and fossils. Angew. Chem., Internat. Ed., 10, 209- 286.

Allred, V.D. (1966) Kinetics of Oil Shale Pyrolysis. Chem. Eng. Prog., 62, 55-60.

Alpern, B. (ed.) (1975) Pétrographie de la matière organique des sédiments, relations avec la paléotempérature et le potentiel pétrolier, Éditions du CNRS, Paris.

Alpern, B., Durand, B., Espitalié, J. and Tissot, B. (1972) Localisation, caractérisation et classification pétrographique des substances organiques sédimentaires fossiles. In Advances in Organic Geochemistry 1971 (H.R. von Gaertner and H.R. Wehner eds.), Pergamon Press, 1-28.

Baker, E.G. (1959) Origin and Migration of Oil. Science, 129, 871-874.

Béhar, F. and Vandenbroucke M. (1987) Chemical Modelling of Kerogens. Org. Geochem., 11, 15-24.

Béhar, F., Vandenbroucke, M., Tang,Y., Marquis, F. and Espitalié, J. (1997) Thermal Cracking of Kerogen in Open and Closed Systems: Determination of Kinetics Parameters and Stoechiometric Coefficients for Oil and Gas Generation. Org. Geochem., 26, 321-339.

Berthelot, M. (1866) Sur 1'origine des carbures et des combustibles minéraux. Ann. Chim. et Phys., 4 e série, 9, 481-483.

Bessereau, G., Guillocheau, F. and Huc, A.Y. (1995) Source Rock Occurrence in a Sequence Stratigraphic Framework: The Example of the Lias of the Paris Basin. In AAPG Studies in Geology, 40, A.Y. Huc Ed., Tulsa, Oklahoma.

Bois, C., Bouché, and Pelet, R. (1982). Global Geological History and the Distribution of Hydrocarbon Reserves. Bull. Am. Assoc. Petr. Geol., 66, 1248-1270.

Bordenave, M., Combaz, A. and Giraud A. (1970) Influence de l'origine des matières organiques et de leur degré d'évolution sur les produits de pyrolyse du kérogène. In Advances in Organic Geochemistry, 1966, G.D. Hobson and G.C. Speers Eds., Pergamon Press, London, 389-405.

Bordenave, M.L. (ed.) (1993) Applied Petroleum Geochemistry, Éditions Technip, Paris.

Bordovsky, O.K. (1965) Accumulation and Transformation of Organic Substances in Marine Sediments. Marine Geology, 3, Elsevier, Amsterdam, 3-114.

Braun, R.L. and Rothman, A.J. (1975) Oil Shale Pyrolysis: Kinetics and Mechanism of Oil Production. Fuel, 54, 129-131.

Bray, E.E. and Evans, E.D. (1961) Distribution of n-Paraffins as a Clue to Recognition of Source Beds. Geochim. Cosmochim. Acta, 22, 2-15.

Breger, I. (ed.) (1963) Organic Geochemistry, Pergamon Press, Oxford.

Brown, F.S., Baedeker, M.J., Nissenbaum, A. and Kaplan, I.R. (1972) Early Diagenesis in a Reducing Fjord, Saanich Iinlet, British Columbia III. Changes in Organic Constituents of Sediment. Geochim. Cosmochim. Acta, 36, 1185-1203.

Buchem van, F.S., Boer de, L., McCave, I.N. and Herbin, J.P. (1995) The Organic Carbon Distribution in Mesozoïc Marine Sediments and the Influence of Orbital Climatic Cycles (England and the Western North Atlantic), In AAPG Studies, 40, A.Y. Huc Ed., Am. Assoc. Petr. Geol., Tulsa, Oklahoma. 
Burrus, J. (1997) Contribution à l'étude du fonctionnement des systèmes pétroliers : Apport d'une modélisation bidimensionnelle. PhD Thesis, École des Mines de Paris, 473.

Calvert, S.E. and Price, N.B. (1971) Recent Sediments of the South-West African Shelf. In Atlantic Continental Margins, London Inst. Geol. Sc., 175-185.

Chiarelli, A. (1973) Étude de nappes aquifères profondesContribution de l'hydrogéologie à la connaissance d'un bassin sédimentaire et à l'exploration pétrolière. $P h D$ Thesis, Univ. Bordeaux, 401.

Claypool, G.E. and Reed, R. (1976) Thermal-Analysis Technique for Source Rock Evaluation: Quantitative Estimate of Organic Richness and Effects of Lithologic Variation. Bull. Am. Assoc. Petr. Geol., 60, 608-626.

Combaz, A. (1964) Les palynofaciès. Rev. Micropal., 205-208.

Combaz, A. (1980) Les kérogènes vus au microscope. In Kerogen (B. Durand Ed.), Éditions Technip, Paris, 55-111.

Connan, J. (1984) Biodegradation of Crude Oils in Reservoir. In Advances in Petroleum Geochemistry, Ed. by Brooks, J. and Welte, D.H., Academic Press, London, 1, 299-335.

Connan, J. (1987) Regards sur la géochimie pétrolière d'aujourd'hui. Bull. Centres Rech. Exploration-Production ElfAquitaine, 11, 103-115.

Correia, M. (1967) Relations possibles entre l'état de conservation des éléments figurés de la matière organique et l'existence de gisements d'hydrocarbures. Oil \& Gas Science and Technology, 22, 1285-1306.

Datsko, V.G. (1959) Organic Matter in Soviet Southern Waters, Ird. Akad. Nauk SSSR Moscow (in Russian).

Datsko, V.G. (1961) Value of Phytoplankton Production in Balance of Organic Material in Marine Reservoir in Azov, Black and Caspian Seas. In Primary Production of Seas and Inland Waters-Minsk (in Russian).

Debyser, J. (1959) Contribution à l'étude géochimique des vases marines. Thèse, Université de Paris.

Debyser, J. and Deroo, G. (1969) Faits d'observation sur la genèse du pétrole. Oil \& Gas Science and Technology, 24, 21-48.

Degens, E.T., Herzen von, R. and Wong H.K. (1971) Lake Tanganyika: Water Chemistry, Sediments, Geological Structure. Naturwissenschaften, 58, 224-291.

Degens, E.T., Herzen von R., Wong, H.K., Deuser, W.G. and Janash, H.W. (1973) Lake Kivu: Structure, Chemistry and Biology of an East African Rift Lake. Geol. Rundschau, 62, 245277.

Degens, E.T. and Ross, D.A. (ed) (1974) The Black Sea: Geology, Chemistry and Biology. Am. Assoc. Petr. Geol. Memoir 20, Tulsa, 629.

De Leeuw, J.W. (1986) High Molecular Weight Markers.In Biological Markers in the Sedimentary Record (R.B. Johns Ed.) Elsevier, Amsterdam, 256-258.

Demaison, G.J. and Moore, G.T. (1980) Anoxic Environments and Oil Source Bed Genesis. Bull. Am. Assoc. Petr. Geol., 64, 1179-1209.

Demaison, G.J. (1984) The Generative Basin Concept. In Petroleum Geochemistry and Basin Evaluation, Ed. by Demaison G.J. and Murris, R.J., Am. Assoc. Petr. Geol. Memoir 35, 1-14.

Demaison, G.J. and Huizinga, B.J. (1991) Genetic Classification of Petroleum Systems. Bull. Am. Assoc. Petr. Geol., 75, 16261643.

Deroo, G. (1976) Corrélations huiles brutes - roches-mères à l'échelle des bassins sédimentaires. Bull. Centre Rech. Pau, 10, 317-335.
Deroo, G., Tissot, B., McCrossan, R.G.and Der, F. (1974) Geochemistry of Heavy Oils of Alberta. Canadian Soc. Petr. Geol. Memoir 3, Calgary, Canada, Stacs Data Services, 148-167.

Disnar, J.R. and Sureau, J.F. (1990) Organic Matter in Ore Genesis: Progress and Perspectives. In Advances in Organic Geochemistry 1989 (B. Durand and F. Béhar Eds), Pergamon Press, 577-590.

Durand, B., Fripiat, J.J. and Pelet, R. (1972) Alkylammonium Decomposition on Montmorillonite Surfaces in an Inert Atmosphere. Clays and Clay Minerals, 20, 19-33.

Durand, B. and Espitalié, J. (1973) Évolution de la matière organique au cours de l'enfouissement des sédiments. C.R. Acad. Sci., Paris, 276, 2253-2256.

Durand, B. and Espitalié, J. (1975) Méthode et appareil permettant l'évaluation rapide du potentiel de production pétrolière de sédiments géologiques sur la base de faibles prélèvements. Brevet national 74/14347 (Rock-Eval).

Durand, B. and Espitalié, J. (1976) Geochemical Studies on the Organic Matter from the Douala Basin (Cameroon) II. Evolution of Kerogen. Geochim. et Cosmochim. Acta, 40, 801-808.

Durand, B., (ed.) (1980) Kerogen, Insoluble Organic Matter from Sedimentary Rocks, Éditions Technip, Paris.

Durand, B., Ungerer, P., Chiarelli, A. and Oudin, J.L. (1984) Modélisation de la migration de l'huile. Application à deux exemples de bassins sédimentaires. Proceedings of the $11^{\text {th }}$ World Petr. Cong., London, 1981, 1, 3-15.

Durand, B. (1987) Du kérogène au pétrole et au charbon: les voies et les mécanismes des transformations des matières organiques sédimentaires au cours de l'enfouissement. Mém. Soc. Géol., France, nouvelle série, 151, 77-95.

Duval, B.C., Cramez, C.and Vail, R. (1998) Stratigraphic Cycles and Major Marine Source Rocks. In de Graciansky C., Hardenbol J., Jacquin T. and Vail, R. (eds.), Mesozoïc and Cenozö̈c Sequence Stratigraphy of European Basins, SEPM Special Publication, 60, 43-51.

Ekweozor, C.M., Okogun, G.I., Ekong, D.E.U. and Maxwell, J.E. (1979) Preliminary Organic Geochemical Studies of Samples from the Niger Delta, Nigeria. Chem. Geol., 27, 39-37.

Engel, M.H. and Macko, S.A. (1993) Organic Geochemistry, Principles and Applications, Plenum Press, 871.

England, W.A. (1990) The Organic Geochemistry of Petroleum Reservoirs. Organic Geochemistry, 16, 415-425.

Engler, C. (1888) D. Chem. Ger., 1816.

Engler, C. (1912) Die Bildung der Haupt-Bestandteile des Erdöls. Petroleum, 7.

Erdman, J.G., Marlett, E.M. and Hanson, W.E. (1958) The Occurrence and Distribution of Low Molecular Weight Aromatic Hydrocarbons in Recent and Ancient Sediments. Am. Chem. Soc., Petroleum Chemistry Div., Preprints Chicago Mtg., 3, 4, 39.

Espitalié, J., Laporte, J.L., Madec, M., Marquis, F., Leplat, P., Paulet, J. and Boutefeu, A. (1977) Méthode rapide de caractérisation des roches-mères, de leur potentiel pétrolier et de leur degré d'évolution. Oil \& Gas Science and Technology, 32, 23-42.

Evans, C.R., Rogers, M.A. and Bailey, N.J.L. (1971) Evolution and Alteration of Petroleum in Western Canada. Chem. Geol., 8 , 147-170.

Fausett, D.W. (1964) Mathematical Study of an Oil Shale Retort. PhD Thesis, Univ. of Wyoming.

Finenko, Z.Z. (1967) Primary Production in Southern Seas. In Problems of Bio-Oceanography (V.A. Vodianitsky, Ird Nau Kova Dumka, Kiev (in Russian). 
Forsman, J. and Hunt, J.M. (1958) Insoluble Organic Matter (Kerogen) in Sedimentary Rocks of Marine Origin. In L.G. Weeks (Ed.), Habitat of Oil: A Symposium. Am. Assoc. Petr. Geol., Tulsa, Oklahoma, 747-778.

Fougeroux de Bondaroy, M. (1770) Second mémoire sur le Pétrole et sur les vapeurs inflammables connues dans quelques parties de l'Italie, Histoire de l'Académie Royale des Sciences, 91.

Galimov, E.M. (1980) $\mathrm{C}_{13} / \mathrm{C}_{12}$ in Kerogen. In Kerogen (B. Durand Ed.), Editions Technip, Paris.

Gold, T. (1979) Terrestrial Sources of Carbon and Earthquake Outgasing. J. of Petr. Geol., 1, 3, 1-19.

Goldstein, T. and Aizenshtat, Z. (1994) Thermochemical Sulfate Reduction, A Review. J. Therm. Anal., 42, 241-290.

Gracianski de, P.C., Deroo, G., Herbin, J., Jacquin, T., Magniez, F., Montadert, C., Müller, C., Ponsot, C., Schaaf, A., and Sigal, J. (1982) Ocean-Wide Stagnation Episodes in the Late Cretaceous. Geol. Rundschau, 75, 17-41.

Graciansky de, P.C., Hardenbol, J., Jacquin, T. and Vail, R. (eds.) (1998) Mesozoïc and Cenozoïc Sequence Statigraphy of European Basins. SEPM Special Publication, 60, 43-51.

Gransch, J.A. and Eisma, E. (1970) Characterisation of the Insoluble Organic Matter of Sediments by Pyrolysis. In Advances in Organic Geochemistry, 1966, (G.D. Hobson and G.C. Speers Eds.) 407-426.

Gutjahr, C.C.M. (1966) Carbonisation Measurements of Pollen Grains and Spores and their Application. Thesis, Leiden.

Huc, A.Y. and Durand, B. (1974). Étude des acides humiques et de l'humine de sediments récents considérés comme précurseurs des kérogènes. In Advances in Organic Geochemistry, 1973, Actes du $6^{\mathrm{e}}$ congrès de géochimie organique, Éditions Technip, Paris, 53-72.

Huc, A.Y. (ed.) (1995). AAPG Studies in Geology No. 40. Am. Assoc. Petr. Geol., Tulsa, Oklahoma.

Huc, A.Y., Carpentier, B., Guehenneux, G. and Magnier, C. (1999) Geochemistry in a Reservoir and Production Perspective. SPE Paper 53146.

Huc, A.Y., Vandenbroucke, M., Bertrand, Ph., Gayet, J. and Stow, D.A.V. (2001) Organic Sedimentation in Deep Offshore Settings: The Quaternary Sediments Approach. Marine and Petroleum Geology, 18, 513-517.

Hubbert, M.K. (1953). Entrapment of Oil under Hydrodynamic Conditions. Bull. Am. Assoc. Petr. Geol., 37, 1954-2026.

Huck, G., and Karweil, J. (1955) Physikalische Probleme der Inkohlung. Brennst. Chem., 36, 1-11.

Hunt, T.S. (1863) Report on the Geology of Canada. In Canadian Geol. Surv., Rep. 983

Hunt, J.M. (1963) Geochemical Data on Organic Matter in Sediments. In V. Bese (Ed.) $3^{\text {rd }}$ International Scientific Conference on Geochemistry, Microbiology and Petroleum Chemistry Proc., KULTURA, Budapest, 2, 394-412.

Hunt, J.M. (1972) Distribution of Carbon in Crust of Earth. Bull. Am. Assoc. Petr. Geol., 56, 2273-2277.

Hunt, J.M. (1979) Petroleum Geochemistry and Geology, Freeman, San Francisco.

Jaccard, A. (1895) Le pétrole, l'asphalte et le bitume au point de vue géologique, Félix Alcan, Paris.

Jeffrey, W.A. and Kaplan, I.R. (1988) Hydrocarbons and Inorganic Gases in the Gravberg-1 Well, Siljan Ring, Sweden. Chemical Geology, 71, 1-3, 237-257.

Kartsev, A.A., Vassoevitch N.B., Geodekian, A.A., Neruchev, S.G., and Sokolov, V.A. (1971) The Principal Stage of Oil Formation. In $8^{\text {th }}$ World Petrol., Cong. Proc., Applied Science Publishers, London, 2, 3-11.
Karweil, J. (1955) Die Metamorphose der Kohlen vom Standpunkt der physicalischen Chemie. Z. Dtsch. Geol. Ges., 107, 132-139.

Kaufman, R.L., Ahmed, A.S. and Elsinger, R.L. (1990) Gas Chromatography as a Development and Production Tool for Fingerprinting Oils from Individual Reservoirs: Application in the Gulf Coast of Mexico. Gulf Coast Section of the SEPM Foundation 9th Annual Research Conference Proceedings, 263282.

Katz, B.J. and Pratt, L. (1993) Source Rocks in a Sequence Stratigraphic Framework. AAPG Studies in Geology, Tulsa, Oklahoma, 37, 237.

Katz, B.J. (1995) Petroleum Source Rocks, Springer-Verlag, 327.

Klemme, H.D. and Ulmishek, G.F. (1991) Effective Petroleum Source Rocks of the World: Stratigraphic Distribution and Controlling Depositional Factor. Bull. Am. Assoc. Petr. Geol., 75, 1809-1851.

Krevelen van, D.W. (1950) Graphical-Statistical Method for the Study of Structure and Reaction Processes of Coal. Fuel, 29, 269.

Krevelen van, D.W. (1961, $2^{\text {nd }}$ ed. 1981) Coal: Typology, Chemistry, Physics, Constitution, Elsevier, Amsterdam.

Krooss, B. (1986) Diffusion of $\mathrm{C}_{1}$ to $\mathrm{C}_{5}$ Hydrocarbons in WaterSaturated Sedimentary Rocks. Erd̈̈l und Kohle-ErdgasPetrochemie, 39, 399-402.

Landais, P., Dubessy, J., Poty, B. and Robb, J.R. (1990) Three Examples Illustrating the Analysis of Organic Matter Associated with Uranium Ores. In Advances in Organic Geochemistry, 1989 (B. Durand and F. Béhar Eds.), Pergamon Press, 601-608.

Largeau, C., Derenne, S., Casadevall, E., Berkaloff, C., Corolleur, M., Lugardon, B., Raynaud, J.F., and Connan, J. (1990) In Advances in Organic Geochemistry, 1989 (B. Durand and F. Béhar Eds.), Pergamon Press, 889-895.

Larter, S.R., Horsfield, B. and Douglas, A.G. (1977) Pyrolysis as a Possible Mean of Determining the Petroleum Generation Potential of Sedimentary Organic Matter. In $3^{\text {rd }}$ International Symposium of Analytical Pyrolysis, Elsevier, Amsterdam, 189202.

Leplat, P. (1967) Application of Pyrolysis Gas Chromatography to the Study of the Non Volatile Petroleum Fraction. J. Gas Chromatography, 5, 128-135.

Lewan, M.D., Winters, J.C. and MacDonald, J.H. (1979) Generation of Oil-Like Pyrolysates from Organic Rich Shales. Science, 203, 897-899.

Leythaeuser, D., Schaefer, R.G. and Yükler, A. (1982) Role of Diffusion in Primary Migration of Hydrocarbons. Bull. Am. Assoc. Petr. Geol., 66, 408-429.

Lind, S.C. (1938) The Science of Petroleum, Oxford University Press, New York, 39-41

Lopatin, N.V. (1971) Temperature and Geological Time as Factors of Carbonification. Akad. Nauk SSSR., Izs. Ser. Geol., 3, 95-106.

Louis, M. and Tissot, B. (1967) Influence de la température et de la pression sur la formation des hydrocarbures dans les argiles à kérogène. $7^{\text {th }}$ World Petr. Cong. Proc., 2, 47-60.

Mackenzie, A.S. (1984) Application of Biological Markers in Petroleum Geochemistry. In Advances in Petroleum Organic Geochemistry (J. Brooks and D.H. Welte Eds.), Academic Press, 115-214.

Matavelli, L. and Novelli L. (1988) Geochemistry and Habitat of Matural Gas in Italy. Organic Geoch., 13, 1-13.

McAuliffe, C.D. (1966) Solubility in Water of Paraffin, CycloParaffin, Olefin, Acetylene, Cycloolefin and Aromatic Hydrocarbons. J. Phys. Chem., 70, 1267-1275. 
McAuliffe, C.D. (1980) Oil and Gas Migration: Chemical and Physical Constraints. In AAPG Studies in Geology no. 10, Problems of Petroleum Migration (W.H. Roberts III and J.R. Cordell Eds), 89-107.

Mc Coy, A.W. and Trager, P. (1919) Notes on Principles of Oil Accumulation. J. Geol., 27, 252-262.

McIver, R.D. (1967) Composition of Kerogen Clue to its Role in the Origin of Petroleum. $7^{\text {th }}$ World Petr. Cong. Proc., 2, 25-36.

McKirdy, D.M., Aldridge, A.K. and Ypma, J.M. (1983) A Geochemical Comparison of Some Crude Oils from Pre-Ordovician Carbonate Rocks. In Advances in Organic Geochemistry, 1981 (M. Bjoroy et al. Ed.), Wiley, Chichester, 99-107.

Mendeleiev, D.I. (1878) Revue Scientif., XIII, 409.

Menschein, W.G. (1959) Origin of Petroleum. Bull. Am. Assoc. Petr. Geol., 43, 925-943.

Moldowan, J.M., Albrecht, P., Philp, R. (1992) Biological Markers in Sediments and Petroleum, Prentice Hall, 411.

Müller, J. and Stoffers, P (1974) Mineralogy and Petrology of Black Sea Sediments. In the Black Sea, Geology, Chemistry and Biology (E.T. Degens and D.A. Ross, Eds.). Am. Assoc. Petr. Geol., Memoir 20, 200-248.

Nogaret, E. (1983) Solubilité des hydrocarbures dans le gaz naturel comprimé. Application à la migration du pétrole dans les bassins sédimentaires. PhD Thesis, École des Mines de Paris.

Oberlin, A., Boulmier, J.L. and Durand, B. (1974) Electron Microscopic Investigation of the Structure of Naturally and Artificially Metamorphosed Kerogen. Geochimica et Cosmochimica Acta, 38, 647-650.

Oh, C.H., Trichet, J., Oh, J.H. and Rouzaud, J.N. (1990) Relation Between the Thermal Behaviour and the Structure of Kerogen in the Gosean Uranium Deposit, Korea. In Advances in Organic Geochemistry, 1989 (B. Durand and F. Béhar Eds.), Pergamon Press, 609-620.

Ourisson, G., Albrecht, P. and Rohmer, M. (1979) The Hopanoids. Paleochemistry and Biochemistry of a Group of Natural Products. Pure Appl. Chem., 51, 709-729.

Pakhomova, A.S. (1961) Organic Matter in the Bottom Deposits of the Caspian, Tr. Gos. Okeanogr. Inst., 6, 18, (in Russian).

Peake, E., and Hodgson, G.W. (1965) Alkanes in Natural Aqueous Systems: Accommodation of $\mathrm{C}_{20}-\mathrm{C} 33 n$-Alkanes in Distilled Water and Occurrence in Natural Water Systems. Bull. Am. Oil Chem. Soc., $56^{\text {th }}$ Annual Spring Meeting, Houston, Texas.

Pelet, R., Debyser, Y., Combaz, A. et al. (1977, 1978, 1979, 1981, 1983) Géochimie organique des sédiments marins profonds. CEPM-CNEXO, Comité d'études géochimiques marines, Éditions du CNRS.

Peters, K.E. and Moldowan, J.M. (1993) The Biomarkers Guide, Prentice Hall, 363.

Philippi, G.T. (1965) On the Depth, Time and Mechanism of Petroleum Generation. Geochim. Cosmochim. Acta, 29, 10211049.

Petrov, A.A. (1987) Petroleum Hydrocarbons, Springer Verlag.

Pratt, W.E. (1943) Oil in the Earth, Lawrence, Univ. of Kansas Press, 106.

Prinzhofer, A. and Huc, A.Y. (1995) Genetic and Post-Genetic Molecular and Isotopic Fractionations in Natural Gases. Chemical Geology, 126, 281-290.

Prinzhofer, A., Mello, M.R. and Takaki, T. (2000) Geochemical Characterization of Natural Gas: A Physical Multivariable Approach and its Applications in Maturity and Migration Estimates. Bull. Am. Assoc. Petr. Geol., 84, 1152-1172.

Radke, M. (1987) Organic Geochemistry of Aromatic Hydrocarbons. In Advances in Petroleum Organic Geochemistry
(J. Brooks, and D.H. Welte, Eds.), Academic Press, London, 2, 141-217.

Reed, J.D., Illich, H.A. and Horsfield, B. (1986) Biochemical Evolutionary Significance of Ordovician oils and their Sources. In Advances in Organic Geochemistry, 1985 (L.D. Leythaeuser and J. Rullkötter Eds.), Academic Press, London, 141-217.

Rice, D.D. and Claypool, G.E. (1981) Generation, Accumulation and Resource Potential of Biogenic Gas. Bull. Am. Assoc. Petr. Geol., 65, 5-25.

Romankevitch, Y.A. (1977) Geochemistry of Organic Matter in the Oceans, Dokl. Acad. Nauk SSSR (in Russian).

Robert, P. (1985) Histoire géothermique et diagenèse organique. Bull. Centres Rech. Explor.-Prod., Elf-Aquitaine, Mém. 8, Pau.

Rullkötter, J. and Michaelis, W. (1990) The Structure of Kerogen and Related Materials. A Review of Recent Progress and Future Trends. In Advances in Organic Geochemistry, 1989 (B. Durand and F. Béhar eds.), Pergamon Press, 829-852.

Sackett, W.M., Bernard, B. and Brooks, J. (1975) Isotopic and Molecular Compositions of Seep Gases in the Gulf of Mexico. Paper Presented at the Southern Regional Organic Geochemists' Meeting, Nov. 1975, Port Aransas, Texas.

Schoell, M. (1983) Genetic Characterization of Natural Gases. Bull. Am. Assoc. Petr. Geol., 67, 2225-2238.

Schneider, F., Wolf, S., Faille, I. and Pot, D. (2000) A 3D Model for Hydrocarbon Potential Evaluation: Application to Congo Offshore. Oil and Gas Science and Technology, 1, 3-13.

Seifert, W.K. and Moldowan, J.M. (1981) Paleoreconstruction by Biological Markers. Geochim. Cosmochim. Acta, 45, 783-794.

Schochardt, M. (1943) Grunlagen und neuere Erkenntnisse der angewandten Braunkohlenpetrographie, Knapp, Halle.

Silverman, S.R. and Epstein (1958) Carbon Isotopic Composition of Petroleums and Other Sedimentary Organic Materials. Bull. Am. Assoc. Petr. Geol., 42, 998-1012.

Silverman, S.R. (1965) Migration and Segregation of Oil and Gas. In Fluids in Subsurface Environments, Am. Assoc. Petr. Geol., Memoir 4, Tulsa, Oklahoma, 53-65.

Shimkus, K.M. and Trimonis, E.S. (1974) Modern Sedimentation in Black Sea. In the Black Sea, Geology, Chemistry and Biology (E.T. Degens and D.A. Ross, Eds). Am. Assoc. Petr. Geol., Memoir 20, 249-278.

Smalley, C. and England, W.A. (1992) Assessing Reservoir Compartimentalisation During Field Appraisal: How Geochemistry Can Help. SPE Paper 25005.

Smith, V. (1954) Studies on the Origin of Petroleum, Occurrence of Hydrocarbons in Recent Sediments. Bull. Am. Assoc. Petr. Geol., 38, 377-404.

Sokolov, V. (1974) Géochimie des gaz naturels, Éditions Mir, Moscou.

Stach, E. (1935) Lehrbuch des Kohlenpetrographie, Borntraeger, Berlin.

Stach, E., Mackowsky, M.Th., Teichmüller, M., Taylor, G.H., Chandra, D. and Teichmüller, R. (1982) Coal Petrology, Borntraeger, Berlin.

Stahl, W.J. (1977) Carbon and Nitrogen Isotopes in Hydrocarbon Research and Exploration. Chem. Geol., 20, 121-140.

Stevens, N., (1956) Origin of Petroleum, A Review. Bull. Am. Assoc. Petr. Geol., 40, 51-61.

Stevens, N., Bray, E.E. and Evans, D. (1956) Hydrocarbons in Sediments of Gulf of Mexico. Bull. Am. Assoc. Petr. Geol., 40, 975-983.

Stone, R.W. and ZoBell, C.E. (1952) Bacterial Aspects of the Origin of Petroleum. Indus. Eng. Chem., 44, 2564-2567. 
Stopes, M.C. (1919) Proc. Roy. Soc. London, B 90, 470.

Stopes, M.C. (1935) Fuel, 14, 4.

Teichmüller, M. (1958) Métamorphisme du charbon et prospection du pétrole. Rev. Ind. Minér., numéro spécial, 99-113.

Teichmüller, M. (1986) Organic Petrology of Source Rocks, State of the Art. In Organic Geochemistry, 10, 581-599.

Tissot, B. (1969) Premières données sur les mécanismes et la cinétique de la formation du pétrole dans les bassins sédimentaires. Simulation d'un schéma réactionnel sur ordinateur. Oil \& Gas Science and Technology, 24, 470-501.

Tissot, B. (1973) Vers l'évaluation quantitative du pétrole formé dans les bassins sédimentaires. Revue Assoc. Fr. Tech. Pétr., 222, 27-31.

Tissot, B., Durand, B., Espitalié, J. and Combaz, A (1974) Influence of the Nature and Diagenesis of Organic Matter in Formation of Petroleum. Am. Assoc. Petr. Geol., 58, 499-506.

Tissot, B., Deroo, G. and Espitalié, J. (1975) Étude comparée de l'époque de formation et d'expulsion du pétrole dans diverses provinces géologiques. Proc. 9th World Pet. Congr., Applied Science Publ., 2, 159-169.

Tissot, B. and Welte, D.H. (1978, $2^{\text {nd }}$ edition 1984) Petroleum Formation and Occurrence, Springer Verlag.

Tissot, B. (1979) Effect on Prolific Petroleum Source Rocks and Major Coal Deposits Caused by Sea Level Changes. Nature, 277, $462-465$.

Tissot, B., Deroo, G. and Herbin, J. (1979) Organic Matter in Cretaceous Sediments of the North Atlantic: Contribution to Sedimentology and Paleogeography. In Deep Drilling Results in the Atlantic Ocean: Continental Margins and Paleoenvironments, Talwian, M., Hay W., Ryan, W.B.F. Maurice Ewing Series, 3, Am. Geoph. Union, 362-374.

Tissot, B. and Bessereau, G. (1982) Géochimie des gaz naturels et origine des gisements de gaz en Europe occidentale. Oil \& Gas Science and Technology, 37, 63-77.

Trask, D. and Wu, C.C. (1930) Does Petroleum Forms in Sediments at Time of Deposition? Bull. Am. Assoc. Petr. Geol., 14, 1451-1463.

Trask, D., Hammar, H.E. and Wu, C.C. (1932) Origin and Environment of Source Sediments of Petroleum, Gulf Publications, Houston.

Trask, D., and Patnode, H.W. (1942) Source Beds of Petroleum. Am. Assoc. Petr. Geol., Tulsa, Oklahoma, 566.

Treibs, A. (1934) Chlorophyll und Häminderivate in bituminösen Gesteinen, Erdölen, Erdwachsen und Asphalten. Ann. Chem., 510, 42-62.

Ungerer, P., Béhar, E. and Discamps, D. (1983) Tentative Calculation of the Overall Expansion of Organic Matter During Hydrocarbon Genesis from Geochemistry Data. Implications for Primary Migration. In Advances in Organic Geochemistry, 1981, (M. Bjoroy Ed.), Wiley, 129-135.
Ungerer, P. and Pelet, R. (1987) Extrapolation of Kinetics of Oil and Gas Formation from Laboratory Experiments to Sedimentary Basins. Nature, 327, 52-54.

Ungerer, P., Espitalié, J., Béhar, F. and Eggen, S. (1988) Modélisation mathématique des interactions entre craquage thermique et migration lors de la formation du pétrole et du gaz. C.R. Acad. Sc. Ser. II, Paris, 927-934.

Ungerer, P., Burrus, J., Doligez, B., Chenet, Y. and Bessis, F. (1990) Basin Evaluation by Integrated 2D Modelling of Heat Transfer, Fluid Flow, Hydrocarbon Generation and Migration. Bull. Am. Assoc. Petr. Geol., 74, 309-335.

Ungerer, P. (1993) Modelling of Petroleum Generation and Migration. In Applied Petroleum Geochemistry (M.L. Bordenave Ed.), Éditions Technip, Paris.

Vassoevich, N.B., Korchagina, Yu.I., Lopatin, N.V. and Chernyshev, V.V. (1969) Principal Phase of oil Formation. Moskow Univ. Vestnik 6, 3-6 (in Russian), English Translation, Int. Geol. Rev. 1970, 12, 11,1276-1296.

Vandenbroucke, M., Bordenave, M.L. and Durand, B. (1993) Transformation of Organic Matter with Increasing Burial of Sediments and the Formation of Petroleum in Source Rocks (1993) In Applied Petroleum Geochemistry (M.L. Bordenave Ed.), Éditions Technip, Paris.

Vernadsky, V.I. (1934) Outlines of Geochemistry ONTI, Gornogeolog. Neft. Izd.

Vially, R. (ed.) (1992) Bacterial Gas, Éditions Technip, Paris.

Waples, D.W. (1980) Time and Temperature in Petroleum Formation/Application of Lopatin's Method to Petroleum Exploration. Bull. Am. Assoc. Petr. Geol., 64, 916-926.

Waples, D.W. (1985) Geochemistry in Petroleum Exploration, Reidel Publish. Cy, Dordrechts, 232.

Welte, D.H., Hagemann, H.W., Hollerbach, A., Leythaeuser, D. and Stahl, W. (1975) Correlation Between Petroleum and Source Rock. 9th World Petr. Cong. Proc., 2, 179-191.

Welte, D.H., Horsfield, B. and Baker, D.R. (1997) Petroleum and Basin Evolution. Insights from Petroleum Geochemistry, Geology and Basin Modelling, Springer-Verlag.

White, D. (1915) Geology: Some Relations in Origin Between Coal and Petroleum. J. Wash. Acad. Sci., 6, 189-212.

White, D. and Thiessen (1913) The Origin of Coal. USBM Bull., 38 .

Whitehead, W.L. (1951) Studies of the Effect of Radio Activity in the Transformation of Marine Organic Materials into Petroleum Hydrocarbons. Fundamental Research on Occurrence and Recovery of Petroleum, American Petroleum Institute, 192-201.

ZoBell, C.E. (1947) Microbial Transformation of Molecular Hydrogen in Marine Sediments with Particular Reference to Petroleum. Bull. Am. Assoc. Petr. Geol., 31, 1709-1751.

Final manuscript received in January 2003 